\title{
GENDER, BIOLOGY, AND THIRD PARTY CUSTODY DISPUTES
}

\author{
WANDA WIEGERS*
}

This article explores the significance of gender difference in the custodial claims of biological parents where de facto care of children has been transferred to unrelated parties. Drawing on media accounts, the trial transcript, and the 2007 decision in Hendricks v. Swan (the "Saskatoon Dad" case), as well as an extensive survey of similar reported cases, the author identifies changes in the construction of birth mothers and genetic fathers over time, both as claimants and non-claimants of custody. The author contends that despite significant differences in their biological roles, mothers and fathers are constructed as formally equal claimants in this context. Both mothers and fathers nonetheless lose out more often than not to third parties, often on grounds of instability rather than bonding. The role of gender in the application of the best interests test to claims by biological parents, particularly the extent to which gendered norms affect assessments of stability, is analyzed. In relation to biological non-claimants, the author addresses the erasure of the birth mother's experience in Hendricks through the use of a formal equality lens and examines assumptions regarding non-disclosure of paternity that privilege the interests of genetic fathers. In conclusion, potential ways of avoiding or minimizing the trauma associated with these cases are briefly canvassed.
Cet article examine l'importance de la différence entre les sexes dans les causes relatives à la garde par des parents biologiques où, en fait, la garde des enfants a été confiée à des parties n'ayant aucun lien de parenté. Encouragée par les médias, la transcription officielle de procès et la décision Hendricks c. Swan (cause du «papa de Saskatoon») de 2007 ainsi qu'une vaste étude de causes semblables, l'auteure détermine des changements dans la construction de mères naturelles et de pères génétiques au fil du temps, à la fois, en tant que demandeur et non-demandeur de la garde. L'auteure prétend que malgré le fait que les rôles biologiques soient très différents, la mère et le père sont officiellement traités en égaux dans ce contexte. Cependant, la plupart du temps, la mère et le père sont perdants au profit d'un tiers, souvent pour raison d'instabilité plutôt que formation de liens affectifs. Le rôle du sexe dans les causes d'intérêt véritable présentées par les parents naturels, tout spécialement la mesure dans laquelle les normes d'après le sexe affectent les évaluations de stabilité y est analysé. Quant aux non demandeurs naturels, l'auteure aborde l'effacement de l'expérience de la mère naturelle dans la cause Hendricks au moyen d'une perspective d'égalité officielle et elle examine les hypothèses relatives à la non-divulgation de la paternité qui privilégie les intérêts des pères génétiques. En conclusion, elle examine rapidement des moyens potentiels permettant d'éviter ou de réduire le traumatisme lié à ces causes.

\section{TABLE OF CONTENTS}



II. BiOLOGY, ILlEgitimACY, AND PARENTAL RightS $\ldots \ldots \ldots \ldots \ldots \ldots 6$

A. Custodial Rights of Fathers $\ldots \ldots \ldots \ldots \ldots \ldots \ldots \ldots \ldots$

B. EQUALITY RightS OF FATHERS UNDER THE CHARTER . . . . . . . . 9

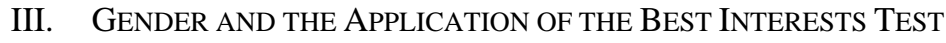

TO BiologicAl CLAiMANTS OF CUSTODY . . . . . . . . . . . . . . . . 12

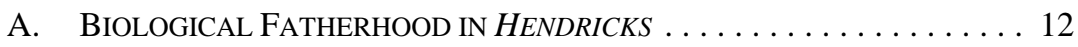

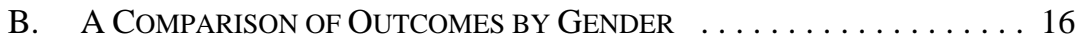

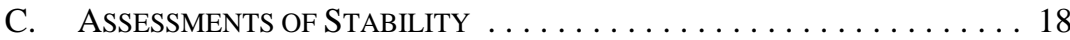

Associate Professor, College of Law, University of Saskatchewan. The author acknowledges the research assistance of Kate Lankenau Crisp, Sarah Burningham, and especially Mary McEwan and Tamara Rock who contributed in invaluable ways to the compilation of the case law surveys examined in the article. Helpful questions and comments were provided by those attending the Gender and Sexuality stream of the Canadian Law and Society Association meetings on 24 May 2009 in Ottawa, where a modified version of this article was presented. The financial assistance of the Social Sciences and Humanities Research Council of Canada (SSHRC) is also gratefully acknowledged. 
IV. The Disappearing Biological PARENT/Mother $\ldots \ldots \ldots \ldots \ldots \ldots . \ldots 28$

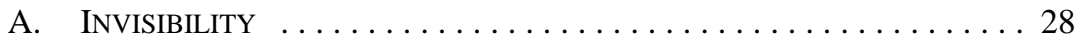





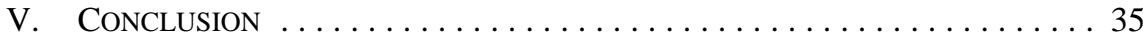

\section{INTRODUCTION}

In 2006, the case of Hendricks became a cause célèbre for the fathers' rights movement. ${ }^{1}$ For 18 months, a man, judicially identified under the pseudonym "Adam Hendricks," contested the de facto custody of an infant boy who had been transferred by his birth mother, "Rose Swan," to the "Turners" shortly after his birth. The father had not cohabited with the mother and was unaware of the pregnancy until a relative of the mother informed him that the child was in the care of another couple. Hendricks' claim for custody was ultimately denied at trial and an appeal was tragically pre-empted by his death in a motor vehicle accident in August 2007.

The facts in Hendricks are relatively uncommon. Biological fathers are often aware of custody transfers or adoption plans and do not seek to disrupt such arrangements. As well, rates of domestic adoptions have declined dramatically in Canada since the 1970s and there are currently far fewer mothers who desire or feel compelled to transfer custody of their children to third parties. ${ }^{2}$ In Hendricks, the genetic father, not having been identified by the mother, had little opportunity to develop a relationship or demonstrate commitment to the child. The birth mother herself wanted a customary adoption consistent with her Aboriginal heritage but did not support Hendricks’ involvement.

In the United States, cases involving claims by "unwed fathers" of newborn children in the care of prospective adoptive parents have generated extensive controversy and academic debate. The Saskatoon Dad case, as Hendricks came to be known, was the first such case in Canada to receive significant press coverage. This unprecedented publicity, facilitated largely by the involvement of several fathers' rights groups, is indicative of the still unsettled nature of fatherhood outside the context of marriage or spousal commitment. The Hendricks case became an important site for debate in Canada over the significance of paternity and the extent of fathers' rights where the claim depends entirely on a genetic tie.

In this article, I explore the significance of gender or sexual difference in the claims of parents where de facto custody of their biological children has been transferred by one parent (usually the mother) or both to unrelated parties. I use the Hendricks case as an anchor or focal point to illustrate how fathers and mothers were constructed in the resolution of this high-profile dispute, referencing press coverage to highlight how both law and popular discourse interact and have important disciplinary effects. I also draw on an extensive survey of reported judicial decisions to identify changes in the legal construction of birth or genetic

Hendricks v. Swan, 2007 SKQB 36, 292 Sask. R. 206 [Hendricks].

Kerry J. Daly \& Michael P. Sobol, “Adoption in Canada” (1994) 32 Canadian Social Trends 3 (between 1981 and 1990, the numbers of children adopted domestically declined by 47 percent). 
parents over time, both as claimants and non-claimants of custody, vis-à-vis parties who have no biological relation to the child. ${ }^{3}$

As a genetic father, ${ }^{4}$ Hendricks' central claim was that he should automatically be granted custody over the Turners and the birth mother's wishes. Although sympathy shifted to some degree as the case unfolded and more details of Hendricks' past were revealed, overall, the print media was sympathetic to this claim. Newspaper accounts constructed fatherhood exclusively in genetic terms and generally cast Hendricks as the victim of, at worst, an active conspiracy against fatherhood and, at best, a legal and administrative system that was biased against fathers. Left largely out of account, though on occasion disparaged, was the birth mother, who was assumed to have chosen to simply drop out of her child's life and to have no ongoing interest in the child's future well-being. Hendricks' position also implicitly assumed that his claim to custody should receive as much weight as the claims of birth mothers, irrespective of the process of gestation and his lack of support for the birth mother during that process. All of these assumptions are highly contestable.

In the United Kingdom, Bren Neale and Carol Smart argue that fatherhood is not only now constructed as essential to child welfare but also transcends both "household boundaries [and] the institution of marriage itself." ${ }^{5}$ In the evolution of what are commonly known as third party claims, ${ }^{6}$ I identify a shift over time away from parental rights to a focus on the child's best interests, which coincides with a shift away from maternal rights towards gender neutrality between biological mothers and fathers. Male claimants in third party disputes only emerged in significant numbers in the late 1980s, but gender has not been an explicit variable in such decisions and the claims of fathers have prevailed at least as often as those of biological mothers. There is thus little evidence that fathers have been prejudiced relative to mothers in the application of the best interests test (although the discretionary and openended nature of the test precludes definitive conclusions). Contrary to the claims of fathers' rights groups, it is more plausibly argued that relevant differences between mothers and fathers are being systematically ignored through the use of a formal equality lens, amounting in effect to a "powerful strengthening of the genetic reading of fatherhood."7

While birth mothers and genetic fathers appear to be constructed equally as claimants of custody, both lose out more often than not to de facto custodians. The increased emphasis on bonding in the assessment of best interests since the Supreme Court of Canada decision

3 In an attempt to isolate the impact of biology, this survey of case law excludes contests between biological parents and persons biologically related to either of them as grandparents or other relatives. A separate discussion of the evolution of custody disputes between unmarried, non-cohabiting fathers and mothers themselves is in progress, as part of a related SSHRC funded research project.

$4 \quad$ Throughout this article, I try to identify the parties with reference to their actual relationship to the child: Hendricks' claim was based on his genetic status, so I refer to him primarily as a genetic father; Rose Swan is identified with reference to her status as both genetic and gestational mother, i.e. birth mother; and the Turners on their actual care of the child over an eight-month period, i.e. as custodial parents. Bren Neale \& Carol Smart, "In Whose Best Interests? Theorising Family Life Following Parental Separation or Divorce” in Shelley Day Sclater \& Christine Piper, eds., Undercurrents of Divorce (Aldershot, U.K.: Ashgate, 1999) 33 at 40. See also Richard Collier \& Sally Sheldon, Fragmenting Fatherhood: A Socio-Legal Study (Portland: Hart, 2008).

$6 \quad$ I use the term "third party" in a technical sense to denote custody contests between biological parents and parties whose claims are not based on biology, but rather on de facto care or on the preference of a biological parent. I use the term purely for ease of reference and do not intend to imply through its usage any particular normative ordering of parent-child relationships.

Collier \& Sheldon, supra note 5 at 198. 
in $\mathrm{King}^{8}$ accounts for some of these outcomes, especially where the child has been in the care of prospective adoptive parents for an extended period of time. However, the effects of bonding appeared to carry little weight in the Hendricks case. As often, both mothers and fathers lose by reason of concerns that are coded in the general language of instability. I attempt to show how gendered norms, as well as other intersecting relations of social inequality, can affect assessments of stability and determinations of good or deserving mothers and fathers. Both birth mothers and fathers may be prejudiced vis-à-vis third parties by their deviation from traditional ways in which mothers and fathers demonstrated stability: for mothers, by way of primary continuous care and for fathers, by way of economic provision, marriage, and the exercise of authority. While both can be disadvantaged in distinctive ways vis-à-vis third parties, birth mothers do not appear to be favoured claimants relative to fathers. Moreover, on the facts of Hendricks, it is difficult to maintain that Hendricks was substantially prejudiced by such norms apart from the trial judge's suspension of access for a one-year period subsequent to the trial.

My survey of case law also reveals that third party custody disputes are increasingly contested as between birth parents, with far more mothers opposing the claims of biological fathers than vice versa. In relation to the status of non-claimants, I contend that the construction of birth parents as equally situated contributes to the erasure of the non-claimant mother's experience, her reasons for the transfer of custody, and her wishes and ongoing concern for the child. In Hendricks, the relative invisibility of the birth mother arguably made it easier to overlook the relevance of her Aboriginal heritage to an assessment of baby Ian's best interests. Drawing on Katharine T. Bartlett's claim that birth mothers need an assurance that their responsible plans for a child will be taken seriously, ${ }^{9} \mathrm{I}$ argue that a birth mother's opposition should, at a minimum, signal a need for careful scrutiny of the father's position and counter any strong presumption in his favour. I also raise questions regarding the assumption underlying much of the press coverage of the Saskatoon Dad case that birth mothers have a moral duty to disclose their pregnancies to birth fathers.

The ultimate disposition of cases such as Hendricks entails a sensitive and complex balancing of the interests of the child, both birth parents and prospective adoptive parents, and, in some cases, the child's community of origin. These cases raise a myriad of issues that cannot be fully canvassed in this article given my focus on the impact of gender. In particular, normative issues such as who should have standing to apply for custody or access, and what standard should be used in the resolution of third party claims, are not comprehensively addressed. ${ }^{10}$ In relation to status, most jurisdictions recognize that either a high level of de facto care or a biological relationship provide standing to advance a claim to custody or access. ${ }^{11}$ Custodial rights are also generally determined by way of a child's best

King v. Low, [1985] 1 S.C.R. 87 [King].

Katharine T. Bartlett, "Re-Expressing Parenthood" (1988) 98 Yale L.J. 293.

The claims in favour of biology and bonding and the ways in which the law mediates competing claims both in third party disputes and the child welfare system are dealt with in another work in progress. The Divorce Act, R.S.C. 1985 (2d Supp.), c. 3, ss. 16(1), (3) allow custody applications by a spouse or person other than a spouse with leave of the court. A person other than a parent requires leave in: Nova Scotia, Maintenance and Custody Act, R.S.N.S. 1989, c. 160, s. 18(2) [Nova Scotia Act]; the Northwest Territories, Children's Law Act, S.N.W.T. 1997, c. 14, s. 20(2) [Northwest Territories Act]; Nunavut, Children's Law Act, S.N.W.T. 1997, c. 14, s. 20(2), as duplicated for Nunavut by s. 29 of the Nunavut Act, S.C. 1993, c. 28 [Nunavut Act]. Some provinces simply provide that a parent or "any other person" may apply for custody: see e.g. Children's Law Reform Act, R.S.O. 1990, c. C.12, s. 21 [Ontario Act]; Family Services Act, S.N.B. 1980, c. F-2.2, s. 129(3) [New Brunswick Act]; Custody Jurisdiction and 
interests rather than parental fitness. ${ }^{12}$ While I cannot canvass all of the normative dimensions of these issues, I do explore the gendered effects of the current law on custodial rights and expose many of its strengths and weaknesses. A fitness test may be less susceptible to some forms of subjective and ideological bias compared to a best interests standard, but the latter can take into account a broader range of factors, including long-term bonding with third parties, the birth mother's reasons for opposing a father's claim (to the extent that these reasons relate to the child's welfare), the complexities of cultural difference, the potential import of intimate violence, and the positive or negative impact of relationships among multiple parties. All of these factors would, or could, more easily be given little, if any, weight on a minimal fitness standard..$^{13}$ In these ways, the Hendricks case is illustrative of the diverse range of circumstances that can legitimately affect outcomes.

In the next section, I provide a brief historical background that illustrates the major changes in the legal status of birth mothers and fathers in relation to children born outside of marriage. In Part III, I turn to a more detailed analysis of the Hendricks case and to an analysis of the role of gender in the application of the best interests test and the extent to which assessments of stability are influenced or affected by gendered norms, among other factors. In Part IV, I examine the position of the biological non-claimants (usually mothers) and the extent to which their interests and wishes are or should be taken account of, as well as the impact of non-disclosure of paternity. In the conclusion, I briefly identify potential

Enforcement Act, R.S.P.E.I. 1988, c. C-33, s. 4 [Prince Edward Island Act]; Children's Act, R.S.Y. 2002, c. 31, s. 33(1) [Yukon Act]. See also Family Relations Act, R.S.B.C. 1996, c. 128, s. 35(1.1) [British Columbia Act] where the definition of person is broad enough to include non-relatives. Other provinces impose specific criteria. In Saskatchewan, The Children's Law Act, 1997, S.S. 1997, c. C-8.2, s. 6 [Saskatchewan Act] permits applications by biological or adoptive parents or others having "a sufficient interest." In Newfoundland, a parent or a "person who has demonstrated a settled intention to treat the child as a child of his or her family," a grandparent, or "a person who had the actual care and upbringing of the child immediately before the application” may apply: Children's Law Act, R.S.N.L. 1990, c. C-13, ss. 27, 69(4) [Newfoundland Act]. In Manitoba, a non-relative may apply for custody in “exceptional circumstances”: Child and Family Services Act, S.M. 1985-86, c. 8, s. 78(2). In Alberta, a non-biological claimant of guardianship must have had care of the child for six months before an application can be made in the absence of good or sufficient reasons: Family Law Act, S.A. 2003, c. F4.5, s. 23(1)(a), (5) [Alberta Act]. There is no specific provision giving third party rights to apply for custody in the Civil Code of Québec: Art. 1260 C.C.Q., although cases have awarded custody to third parties: see e.g. C.(G.) v. V.-F. (T.), [1987] 2 S.C.R. 244.

The best interests or welfare of the child is the governing test in all Canadian jurisdictions: Divorce Act, ibid., s. 16(8); British Columbia Act, ibid., s. 24(1); The Family Maintenance Act, R.S.M. 1987, c. F20, s. 2(1); New Brunswick Act, ibid., s. 129(2); Newfoundland Act, ibid., s. 31(1); Northwest Territories Act, ibid., s. 17(1); Nunavut Act, ibid., s. 17(1); Ontario Act, ibid., s. 24; Prince Edward Island Act, ibid., s. 3(2); Saskatchewan Act, ibid., s. 8; Yukon Act, ibid., s. 1. See also Nova Scotia Act, ibid., s. 18(5), where the welfare of the child is the paramount consideration; Civil Code of Québec, ibid., art. 33: "[e]very decision concerning a child shall be taken in light of the child's interests and the respect of his rights." Alberta formerly applied a fitness test to "legal strangers" and a best interests test to "legal guardians”: see e.g. Bowes v. Gauvin, 2001 ABCA 206, 286 A.R. 395. The Alberta Act, ibid., s. 18 now makes best interests the decisive test and uses the language of guardianship, parenting time, and parenting orders rather than custody and access. Because this article deals with decisions across common law jurisdictions in Canada, I use the term custody to describe the third party disputes at issue. Since many of the custody claims involve claims for adoption, it should be noted that the issuance of final orders for adoption also generally depends on an assessment of the child's best interests, e.g. Adoption Act, R.S.B.C. 1996, c. 5, s. 2; Child, Youth and Family Enhancement Act, R.S.A. 2000, c. C-12, s. 58.1; The Adoption Act, 1998, S.S. 1998, c. A-5.2, s. 16(1); Child and Family Services Act, R.S.O. 1990, c. C.11, s. 146(1); Child and Family Services Act, R.S.N.S. 1990, c. 5, s. 78(1).

13 Both standards may be criticized for a focus on the child or parent as isolated individuals rather than on the relational interests that deeply connect them. As standards that are universal and impartial in form, both may also tend to obscure different cultural contexts and the material and social relations of inequality that profoundly affect both caregivers and children. For a critique of the ideological form of the best interests standard in the context of child welfare law and First Nations, see Marlee Kline, "Child Welfare Law, 'Best Interests of the Child’ Ideology, and First Nations” (1992) 30 Osgoode Hall L.J. 375. 
ways of avoiding or minimizing the trauma associated with these dilemmas, which require further evaluation and debate.

\section{Biology, ILlegitimacy, AND PARENTAL Rights}

\section{A. Custodial Rights OF FAthers}

In English common law, the father-child relationship was defined directly by marriage rather than biology. ${ }^{14} \mathrm{~A}$ father had automatic authority and guardianship of his "legitimate" children and had the right to custody over both the mother and other parties unless he was found guilty of misconduct. Children born within marriage were subject to a presumption of legitimacy that could be rebutted only by proof beyond a reasonable doubt. By contrast, a child born outside of lawful wedlock was filius nullius, a child without ancestors or rights to a father or mother. Mothers, however, most often assumed de facto care of the child and, by the end of the 1800s, their wishes were considered primary unless clearly detrimental to the child's interests. ${ }^{15}$ Fathers and mothers were subject to a statutory duty to pay support for children dependent on parish relief as early as 1576 in England, ${ }^{16}$ but a number of social and legal impediments to obtaining affiliation orders (the need for corroboration, the intense social stigma attached to unwed mothers, etc.) mitigated these burdens for fathers and limited their liability in most jurisdictions until the 1980s. ${ }^{17}$ Other legal disabilities imposed on children born out of wedlock included a lack of entitlement to intestate succession and a presumption against testamentary dispositions.

At common law then, the father was in no better position than a stranger to the "illegitimate" child. ${ }^{18}$ In equity, however, courts were broadly empowered to promote the overall welfare of the child ${ }^{19}$ and on this basis a few early decisions in Saskatchewan granted custody or access to fathers of illegitimate children. ${ }^{20}$

In the 1950s, a trilogy of Supreme Court of Canada decisions affirmed the significance of parental rights by allowing birth mothers to regain custody of their illegitimate children from pre-adoptive parents. ${ }^{21}$ In one of these cases, Martin, Cartwright J. explicitly stated that the mother had a right to custody of an illegitimate child unless she was shown to be unfit

14 For a legal history of illegitimacy, see Harry D. Krause, Illegitimacy: Law and Social Policy (Indianapolis: Bobbs-Merrill, 1971); Jenny Teichman, Illegitimacy: An Examination of Bastardy (Ithaca, N.Y.: Cornell University Press, 1982).

15 Barnardo v. McHugh, [1891] A.C. 388 at 398-99 (H.L.); Re C., an infant (1911), 25 O.L.R. 218 (Ct. J.).

16 See Law Reform Commission of Nova Scotia, The Legal Status of the Child Born Outside of Marriage in Nova Scotia: Final Report (Halifax: Law Reform Commission of Nova Scotia, 1995) at 4-5.

17 See e.g. Lori Chambers, Misconceptions: Unmarried Motherhood and the Ontario Children of Unmarried Parents Act, 1921-1969 (Toronto: University of Toronto Press for the Osgoode Society of Canadian Legal History, 2007).

18 Re Maher (1913), 12 D.L.R. 492 at 494 (Ont. H.C.). Some cases also favoured mothers on the basis of tender years, if other things were equal: see e.g. Re T. (1970), 3 R.F.L. 100 (B.C.S.C.).

$19 \quad$ R. v. Nash (1883), 10 Q.B.D. 454 at 456 (C.A.).

$20 \quad$ See Re Bestwick v. Auston (1909), 11 W.L.R. 73 (Sask. S.C.); Frost v. Belovich, [1943] 3 W.W.R. 337 (Sask. K.B.) (both providing fathers with custody, in the latter case because the mother was living an immoral life with another man); Alderman v. Gegner (1961), 32 D.L.R. (2d) 71 (Sask. Q.B.) (granting the father a right in equity to apply for access). See also Re C. (M.A.) (A Minor), [1966] 1 All E.R. 838 (C.A.); Re A. (An Infant), [1955] 2 All E.R. 202 (C.A.) (the Court of Appeal granted custody to the father and his wife and the father's brother and sister-in-law respectively, against the mothers' wishes for adoption).

21 Martin v. Duffell, [1950] S.C.R. 737 [Martin]; Agar v. McNeilly (1957), [1958] S.C.R. 52; Hepton v. Maat, [1957] S.C.R. 606. 
or to have abandoned the child. ${ }^{22}$ However, a subsequent shift away from a parental rights focus began as early as 1973 when the Ontario Court of Appeal cited the best interests of the child as the paramount consideration in mother-third party custody contests. ${ }^{23}$ In King in 1985, the Supreme Court of Canada endorsed this broader, more child-centred approach. Although parental claims were entitled to serious consideration, they could be outweighed by an assessment of which party would best secure the "healthy growth, development and education of the child." ${ }^{24}$ Returning a child to the care of the birth mother was no longer inherently assumed to further his or her best interests.

A survey of a large number of reported decisions involving the resolution of custodial claims between birth parents and unrelated third parties (excluding child apprehensions and step-parent claims) prior to 1985 reveals how sharply claims and outcomes were differentiated by gender. ${ }^{25}$ Up to the mid-1980s, mothers advanced claims in 36 of these decisions, but secured the return of their children in only 16, which is indicative of the magnitude of other variables and the beginning of a shift away from a maternal preference. Mothers and fathers jointly claimed custody in 12 cases, succeeding in five (where the child was subsequently legitimated by the marriage of the biological mothers and fathers). Fathers claimed sole custody against unrelated parties in only three cases, all without success. ${ }^{26}$ That unmarried genetic fathers claimed in only two of these suggests that fathers were either disinterested or assumed, often correctly, that they had no legal status to advance such claims. ${ }^{27}$ Although mothers could thus often unilaterally decide either to rear their children or place them for adoption, having custody of their child was viewed primarily as a burden, if not a punishment for immoral conduct, and unmarried mothers commonly experienced intense social stigma and impoverishment. ${ }^{28}$ For fathers, the scarcity of claims is not surprising as both law and social norms constructed unwed fathers primarily as unattached

22 Her wishes prevailed "unless 'very serious and important' reasons require[d] that, having regard to the child's welfare, they must be disregarded”: Martin, ibid. at 744. See also Re Logue and Burrell (1970), [1971] 1 O.R. 255 (C.A.) (granting custody to the mother, not the father, on this basis even though the Infants Act had identified both as joint guardians unless otherwise ordered).

$23 \quad$ Re Moores and Feldstein, [1973] 3 O.R. 921 (C.A.).

$24 \quad$ King, supra note 8 at 101 , para. f.

25 These cases were identified through Quicklaw using search terms such as "dispensing with consent," "adoption," "non-parent” in family law, and "non-parent and custody” up to 1 January 1985. Cases identified through the search terms were then noted up and cases cited within these cases were checked. A more expansive ongoing search of cases involving custody claims by unmarried fathers in British Columbia, Saskatchewan, and Ontario revealed additional cases.

26 Price v. Cargin, [1956] 4 D.L.R. (2d) 652 (Ont. C.A.), aff'd [1957] S.C.R. 341 (a divorced father sought custody of a child placed by the mother with third parties for five years, during which time he had little access and paid little support); L. v. Children's Aid Society of Toronto [1976] 24 R.F.L. 134 (H.C.J.) (the registered father had successfully challenged a wardship order obtained without notice to him as a known and probable father (see Children's Aid Society of Metropolitan Toronto v. Lyttle (1972), [1973] S.C.R. 568), but lost his claim to custody based on an assessment of the child's best interests); Re Ramseden and Children's Aid Society of the County of Kent, [1979] 2 S.O.R. (2d) 470 (Co. Ct.).

27 Many adoption statutes have limited the rights of unmarried fathers to notice and to withhold consent to adoption, see e.g. Re Wade and Director of Child Welfare (1981), 127 D.L.R. (3d) 508 (Nfld. C.A.); post-1985 see L.L. v. Saskatchewan (Department of Social Services) 2003 SKQB 8, 229 Sask. R. 49; and most recently, LaCarte v. Macdonald, [2009] O.J. No. 2972 (S.Ct.) (QL) [LaCarte].

28 Carol Smart, "'There is of Course the Distinction Dictated by Nature': Law and the Problem of Paternity” in Michelle Stanworth, ed., Reproductive Technologies: Gender, Motherhood, and Medicine (Cambridge, U.K.: Polity Press, 1987) 98 at 109; Mary L. Shanley, “Fathers’ Rights, Mothers’ Wrongs? Reflections on Unwed Fathers' Rights and Sex Equality” in Uma Narayan \& Julia J. Bartkowiak, eds., Having and Raising Children: Unconventional Families, Hard Choices and the Social Good (University Park, Pa.: Pennsylvania State University Press, 1999) 39 at 44. 
sexual beings, having little ongoing interest in or connection with their offspring unless they chose to exercise responsibility through marriage. ${ }^{29}$

Since 1985, as the discussion in Part III illustrates, there has been a marked increase in the number of claims by fathers, along with a few successes. This change is consistent with a surge in the number of custodial claims by fathers in contests against unmarried mothers since the mid-1980 $\mathrm{s}^{30}$ and with a shift away from a maternal preference in the assessment of the child's best interests in the context of separation and divorce. ${ }^{31}$ In 1973, the Supreme Court of Canada rejected the doctrine that mothers are by nature better parents of children of tender years (under seven) as a rule of law..$^{32}$ The 1985 Divorce Act, through s. 16(10), promoted maximum contact with fathers as a governing principle in custody law. ${ }^{33}$ The Divorce Act also stipulated that the best interests of the child was to be the sole (rather than a primary or paramount) consideration in custody claims. ${ }^{34}$ This change mandated that all considerations be screened through the prism of children's interests and rendered equity or fairness as between the parents an irrelevant concern. ${ }^{35}$ Legislation in most provinces followed the federal lead. Saskatchewan's The Children's Law Act, 1997 also prescribed that a court "make no presumption and draw no inference as between parents that one parent should be preferred over the other on the basis of the person's status as a father or mother."36 This provision appears to require that mothers and fathers be treated as formally equal, even at birth, notwithstanding the possible lack of the father's involvement and support during the pregnancy and the possibility of a closer psychological and physical bond between mother and child through the unique process of gestation and childbirth.

An extensive assessment of the process of legal and social change in this context is beyond the scope of this article; however, a number of other changes likely contributed to a revisioning of the claims of unmarried biological fathers. Between 1978 and 1990, the status of illegitimacy was abolished in most provinces as were related limitations on child support and intestacy. ${ }^{37}$ Abolition ended the degraded status of illegitimacy for the child in law, but also simultaneously expanded the role of the unmarried father insofar as he was recognized as having the same responsibilities with respect to the child as if she or he were legitimate. The abolition of impediments to support and intestacy and the intensive privatization of support in the neo-liberal state likely made more obvious and compelling the claim that rights should correspond in greater measure to responsibilities. ${ }^{38}$ Advances in reproductive technologies, the use of more reliable and accessible indicators of paternity, the liberalization of divorce, and the recognition of cohabitation as a source of legal rights

Collier \& Sheldon, supra note 5 at 178.

This represents preliminary results from an examination of custody contests between unmarried birth parents in Saskatchewan and Ontario.

See generally Susan B. Boyd, Child Custody, Law, and Women's Work (Toronto: Oxford University Press, 2003).

Talsky v. Talsky (1975), [1976] 2 S.C.R. 292.

Divorce Act, supra note 11.

Ibid., s. 16(8).

For a critique of this singular focus on the child's interests, see Bartlett, supra note 9 at 303-304.

Saskatchewan Act, supra note 11, s. 8(c). See also Ontario Act, supra note 11, s. 20, which provides that mothers and fathers are equally entitled to custody.

Nova Scotia still allows for legitimation of children by statute but the material effects of illegitimate status appear to have been abolished.

See Alberta Health and Social Development, Public Attitudes Toward Illegitimacy in Alberta: A Report to Alberta Health and Social Development by Michael E. Manley-Casimir (Edmonton: Alberta Health and Social Development, 1975) at 47-8. 
combined to reduce the significance of marriage and elevate the role of biology. ${ }^{39}$ Rising divorce and declining birth rates, as well as dramatically reduced rates of domestic adoption, have also likely afforded men fewer alternative opportunities to father and parent children, thereby increasing the frequency of their claims to children born outside of marriage and cohabitation.

\title{
B. EQUALITY RIGHTS OF FATHERS UNDER THE CHARTER
}

A similar shift - from maternal preference to formal equality — is discernable in the resolution of equality claims under the Canadian Charter of Rights and Freedoms ${ }^{40}$ involving unmarried parents. While claims on behalf of children for prejudicial treatment as a result of illegitimacy were generally successful and indeed appeared instrumental in achieving legislative reform in some jurisdictions, ${ }^{41}$ challenges based on alleged discrimination against unmarried fathers initially generated mixed outcomes. ${ }^{42}$ In the adoption context, the varied outcomes signalled different views of the significance of biological difference between birth mothers and fathers. For example, the Ontario Divisional Court in C.E.S. found that the biological parents, as a result of their different reproductive roles, were not similarly situated with respect to the purpose of ensuring that children whose parents are unwilling or unable to care for them receive early placement in a permanent home:

\begin{abstract}
The mother because of physical necessity has shown responsibility to the child. She carried and gave birth to it. The casual fornicator who has not demonstrated any interest in whether he did cause a pregnancy or demonstrate even the minimum responsibility to the child ... cannot be said to be similarly situated to the mother. The statute recognizes as a parent, a father who demonstrates the minimum interest in the consequences of his sexual activity. Most fathers are defined as parents. Only those who do not demonstrate some responsibility to the child are not. It is thus apparent to us that the different statutory treatment of the two persons is based upon their respective demonstrated responsibility to the child, not upon their different sexes. $^{43}$
\end{abstract}

Here, birth mothers and fathers were distinguished by their biological roles and the exclusion of fathers who failed to demonstrate responsibility or interest in their genetic offspring before placement was found to be consistent with the objective of promoting expedient and final adoptions. Likewise, in the "biology plus" decisions of the U.S. Supreme Court, an

Part I of the Constitution Act, 1982, being Schedule B to the Canada Act 1982 (U.K.), 1982, c. 11 [Charter].

$41 \quad$ See e.g. Williams v. Haugen (1988), 55 D.L.R. (4th) 720 (Sask. C.A.) (striking down a one-year limitation period on child support applications as discrimination against children and unmarried mothers); Panko v. Vandesype (1993), 101 D.L.R. (4th) 726 (Sask. Q.B.) (overturning a bar on child support applications where a father was not in default of an agreement on the same grounds).

42 See Philips v. Nova Scotia (Social Assistance Appeal Board) (1986), 76 N.S.R. (2d) 240 (C.A.); Ref Re Family Benefits Act (Nova Scotia) (1986), 75 N.S.R. (2d) 338 (C.A.) (striking down a statutory provision providing state benefits to single mothers with dependent children only). But see Shewchuk v. Ricard (1986), 28 D.L.R. (4th) 429 (B.C.C.A.) (upholding legislation that allowed only single mothers to sue for support). For an analysis identifying privatization of support as the common underlying theme, see Judy Fudge, "The Privatization of the Costs of Social Reproduction: Some Recent Charter Cases" (1989) 3 C.J.W.L. 246; Susan B. Boyd, "The Impact of the Charter of Rights and Freedoms on Canadian Family Law” (2000) 17 Can. J. Fam. L. 293.

43 C.E.S. v. Children's Aid Society of Metropolitan Toronto (1988), 64 O.R. (2d) 311 at 475 (H.C.J.) [C.E.S.]. See also Re D.T. (1992), 113 N.S.R. (2d) 74 (S.C. (A.D.)). 
unmarried father has a constitutional right to challenge an adoption or child welfare proceeding only if he has otherwise assumed responsibility or demonstrated a commitment to a parental relationship with the child. ${ }^{44}$

By contrast, the lack of provision for the birth father's consent to adoption was found in N.M. v. British Columbia (Superintendent of Family and Child Services) to constitute a violation of s. 15 that was not saved by s. $1 .{ }^{45}$ Justice Huddart held that the biological differences between mothers and fathers were not relevant to the purpose of the adoption statute, which she identified as the establishment of a new home for the care and nurturance of children and the severance of the relationship with the child's birth parents. While the capacity of fathers to nurture and care for children is not in doubt, genes are implicitly used here to give fathers an interest equal to birth mothers in the care of children. The father's experience of parenthood as genetic contribution (achieved through sexual intercourse) functions as the baseline for granting fathers equal rights; ${ }^{46}$ the mother's far more significant role over the nine-month period of gestation and childbirth is of little account as is the lack of the father's involvement or support of the mother during her pregnancy (what Barbara Bennett Woodhouse refers to as "gestational fatherhood" 47 ).

More recently, in Trociuk, the Supreme Court of Canada found that a statute allowing a mother to refuse to acknowledge the birth father on a child's birth certificate arbitrarily denied him the opportunity to register his particulars and participate in choosing the child's surname in violation of s. $15 .^{48}$ The disparate treatment of the father and mother in this context constituted discrimination because it implied that “a father's relationship with his children is less worthy of respect than that between a mother and her children" ${ }^{49}$ and further confused or unfairly associated innocent fathers with those who were justifiably excluded (by reason of rape or incest). ${ }^{50}$

The father in Trociuk had little actual contact with his children or role in their upbringing, although he had obtained court ordered access. He had demonstrated a measure of responsibility through regular support payments and had also provided some emotional support and physical care for the mother shortly after the birth of the triplets. However, his claim did not appear to depend on any of these facts but was, rather, triggered simply by his genetic relationship to the children. As Hester Lessard argues, the decision reduces parenthood to "disembodied sperm and ova,"51 and reinscribes a "heterosexual narrative" for

See Stanley v. Illinois, 405 U.S. 645 (1972); Quillon v. Walcott, 434 U.S. 246 (1978); Caban v. Mohammed, 441 U.S. 380 (1979); Lehr v. Robertson, 463 U.S. 248 (1983) (the father had failed to register in the birth registry and Stevens J. noted at 261 that the "mere existence of a biological link does not merit equivalent constitutional protection”). See also Michael H. v. Gerald D, 491 U.S. 110 (1989), (privileging an intact marital unit (mother and her husband) over a biological father even though he had a relationship to the child). Where a parental right is established, the test is unfitness rather than the best interest of the child.

$45 \quad$ (1986), 34 D.L.R. (4th) 488 (B.C.S.C.).

46 See Cecily L. Helms \& Phyllis C. Spence, “Take Notice Unwed Fathers: An Unwed Mother’s Right to Privacy in Adoption Proceedings" (2005) 20 Wis. Women's L.J. 1 at 6; Jennifer S. Hendricks, "Essentially a Mother" (2007) 13 Wm. \& Mary J. Women \& L. 429 at 451.

"Hatching the Egg: A Child-Centered Perspective on Parents' Rights" (1993) 14 Cardozo L. Rev. 1747. Trociuk v. British Columbia (A.G.), 2003 SCC 34, [2003] 1 S.C.R. 835 [Trociuk].

Ibid. at para. 21.

Ibid. at para. 23.

Hester Lessard, "Mothers, Fathers, and Naming: Reflections on the Law Equality Framework and Trociuk v. British Columbia (Attorney General)" (2004) 16 C.J.W.L. 165 at 197. 
parental relations, ${ }^{52}$ both in constitutional law and the legal ordering of family relations more generally.

Justice Deschamps, for the majority in Trociuk, was careful, however, to define the violation of s. 15 as not simply disparate, but also arbitrary treatment since there was no process through which the father's interests could be openly assessed against the interests of mothers and children. ${ }^{53}$ In concrete terms then, the right to sex equality amounted not to a guaranteed substantive outcome favouring the father, but rather, to an opportunity to be heard and have his claim adjudicated. In Trociuk, the substantive legal standard appeared to remain in large part that of the children's best interests, but it was unclear how broadly or in what terms these interests would be defined, or what weight they would be assigned in relation to the father's or mother's interests. In the context of third party custody, the opportunity to apply for custody would presumably satisfy the right to equality pursuant to Trociuk, even though the ultimate outcome is determined solely or primarily by reference to the best interests of the child. ${ }^{54}$

Since Trociuk, the extent to which equality requires that biological differences between mothers and fathers be ignored is not entirely clear. Most birth registry statutes allow one parent (who, in practice, is typically the birth mother) to register as the child's parent provisionally, subject to applications to change or correct the record. ${ }^{55}$ Guardianship provisions having a disparate impact on fathers have to date withstood Charter challenges in light of the mother's physical presence at birth, the need to ensure the existence of a guardian in all situations, and the opportunity to contest guardianship through a court application. ${ }^{56}$ In terms of adoption, some provincial governments have amended adoption statutes to require the consent of biological fathers (unless dispensed with) or relied on birth registry systems. ${ }^{57}$ The former process effectively places an onus on birth mothers to disclose paternal identity before an adoption claim can proceed, potentially involving substantial delays and incursions into the mother's privacy, ${ }^{58}$ while the latter places the onus on fathers to register an interest if they want to preserve an opportunity to parent. Although adoptions are heavily regulated in most jurisdictions, where custody has simply been transferred by the birth mother to third parties, there is currently no process requiring either notice or legal

$52 \quad$ Ibid. at 192

$53 \quad$ Trociuk, supra note 48 at para. 44.

54 See Young v. Young, [1993] 4 S.C.R. 3 at para. 83, where L'Heureux-Dubé J. indicated that the best interests test was "value neutral” but also consistent with the objectives of the Charter in its protection of a vulnerable group.

55 See e.g. D.C. v. W.A. (2003), 48 R.F.L. (5th) 21 (Ont. Ct. J.).

56 For example, the Saskatchewan Act, supra note 11, s. 3(2) provides that "where the parents have never cohabited after the birth of the child, the parent with whom the child resides is the sole legal custodian of the child." See Giles v. Beisel, 2004 SKQB 330, [2006] 2 W.W.R. 724 (dismissing a challenge under s. 7). But see J.F.M. v. V.P., 2004 ABQB 208, 366 A.R. 239 [J.F.M.] where Lee J. was prepared, in obiter, to strike down the guardianship provisions of the former Domestic Relations Act finding that they did not minimally impair the right to gender equality under the Charter. In Re T.D.E., 2008 ABQB 563, 58 R.F.L. (6th) 198, Kent J. found that the Adoption Act established a complete code for adoption proceedings in Alberta and that granting automatic guardianship to a biological father who may have had little contact with the mother was inconsistent with the goal of expediting adoptions under the Act.

57 British Columbia has had a birth registry system in place since 1996. Saskatchewan recently expanded the definition of birth parent to include the "biological father": The Adoption Act, 1998, supra note 12, s. 2, but the Ontario Act remains similar to the former Saskatchewan Act: see Child and Family Services Act, supra note 12, s. 137(1); LaCarte, supra note 27 (questioning the constitutional status of Ontario's provision).

$58 \quad$ For an analysis of such privacy concerns, see Helms \& Spence, supra note 46. 
oversight until a court application for custody, access, or adoption is made by one of the affected parties. ${ }^{59}$

Acknowledging the different positions of the biological parents raises several significant risks from the perspective of achieving substantive gender equality. There is the risk of essentializing biological roles by reinforcing assumptions that women are by nature the nurturers of children and that men are inherently less capable of caring for infants. ${ }^{60}$ As importantly, acknowledging this difference might also encourage increased scrutiny and state regulation of gestational care. There is the further risk of objectifying children if custodial rights were to be determined strictly by the relative contributions of men and women.

However, ignoring the different biological positioning of birth mothers and fathers gives rise to the risk of reinforcing a cruder genetic essentialism, which suggests that genes are central to, and the most important part of, identity. It also produces an erasure of the birth mother's experience, ignoring the crucial role mothers play in the very existence of the child and the discomfort, effort, and risk of pregnancy and childbirth. A mother's experience of pregnancy can affect her in profound ways both physiologically and psychologically. ${ }^{61}$ Rose Swan nearly died after giving birth to baby Ian as a result of complications that required two surgeries and intensive care for several days. ${ }^{62}$ Obscuring the process of gestation finally obscures the possibility of a stronger emotional bond with the child as well as the risks and dilemmas mothers face in planning for their children's future in the course of pregnancy. These risks were, I argue, evident in Hendricks.

\section{GENDER AND THE APPLICATION OF THE Best INTERESTS TEST TO Biological Claimants of CUSTODY}

\section{A. BIOLOGICAL FATHERHOOD IN HENDRICKS}

“I’m left wondering: How do you define a father now?”: Adam Hendricks, after the judgment of Smith J. ${ }^{63}$

Swan, the birth mother in Hendricks, was struggling with substance abuse and wanted a customary adoption that would acknowledge her Aboriginal heritage and allow her access to the child. Swan was referred by her sister to Linda Turner, who was not herself Aboriginal, but had worked on a long-term basis as a family therapist for a First Nation. Turner and her husband were found at trial to have a secure annual income of approximately $\$ 100,000$ and a stable, emotionally healthy, 12-year relationship. Under a guardianship and

Home Studies, probationary periods, post-placement reports, and judicial and administrative oversight on placements are commonly required under adoption statues. See below, text accompanying notes 23436 for a discussion of recent amendments in Ontario and the United Kingdom.

60 To the contrary, some recent research suggests that nurturing behavior by men stimulates hormonal change in them: see John Hoffman, “Basic Instinct” Today's Parent (February 2003), online: Today's Parent <http://www.todaysparent.com/lifeaspartent/article.jsp?content=1225399\&\&page=1>.

61 Shanley, supra note 28 at 52. See also Naomi Cahn, "Birthing Relationships” (2002) 17 Wis. Women’s L.J. 163 at 189-90 [Cahn, "Birthing Relationships"]; Carol Sanger, "Separating from Children" (1996) 96 Colum. L. Rev. 375.

62 Hendricks v. Swan (29 January 2007), Saskatoon Q.B. FLD No. 117 of A.D. 2006 at 569-72 (Sask. Q.B.) [Trial Transcript] [on file with author].

63 Kelly Patrick, "Biological dad barred from seeing infant son: Judge awards custody to guardian couple" National Post (30 January 2007) A9. 
custody agreement, Swan transferred custody of her child to the Turners directly from the hospital. The agreement entered into between the Turners and Swan shortly after the child's birth provided that the birth father of the child was unknown and had not acknowledged paternity or supported the mother during her pregnancy. Adam Hendricks was unaware of Swan’s pregnancy until informed by Swan's stepbrother.

While Hendricks lost his claim to custody at trial, he appeared to win in the court of public opinion. ${ }^{64}$ His claim to custody received extensive and overall sympathetic newspaper coverage $^{65}$ - in itself a significant victory for fathers' rights groups. As an "unusual, unique, personal stor[y] involving drama and/or conflict," ${ }^{66}$ the case qualified on its own as a newsworthy event, but Hendricks also actively pursued media attention as a way of increasing public support and funding his litigation costs. ${ }^{67}$ His media presence was bolstered by the involvement of several fathers' rights groups including Fathers 4 Justice, the Canadian Council for the Rights of Children (CCRC), and Fathers are Capable Too (FACT) ${ }^{68}$ Given the reluctance of the Turners, his supposed adversaries, to engage in a media campaign, ${ }^{69}$ Hendricks was able to define the issues up to the date of trial and focus attention predominantly on his individual claim as the genetic father.

The risk of encouraging genetic essentialism was manifestly evident in press coverage of the Hendricks case. In most reports, biology appeared as a taken for granted basis for an emotional attachment on the part of Hendricks to the child and implicitly as the basis for a legal entitlement to custody or access. One report noted that even though Hendricks was proven to be the biological father, he had "not seen his son." ${ }^{\text {, }}$ Such accounts generally did not address the issue of the child's interests or welfare, ${ }^{71}$ even in relation to the genetic tie, perhaps because the latter was assumed to generate an innate sense of the child's best interests. One writer doubted whether a judge would deny a mother rights to her own child: "Why does the legal system continually treat men as second-rate, or even disposable, parents?"72 Columnists in The Star Phoenix and National Post generally portrayed Hendricks as a victim, initially as someone who was cheated out of his son by virtue of some conspiracy

Deana Driver, "Family law and public opinion come to a head in Sask. custody dispute" The Lawyers Weekly (9 February 2007) 1.

A ProQuest search revealed that the Hendricks case was extensively covered in the Star Phoenix (25 items) and Leader-Post (five items), and while it appeared only once in the Globe and Mail, Toronto Star, and Edmonton Journal, it received significant coverage in the National Post (11 items).

Dorothy E. Chunn, “'Take It Easy Girls’: Feminism, Equality, and Social Change in the Media” in Dorothy E. Chunn, Susan B. Boyd \& Hester Lessard, eds., Reaction and Resistance: Feminism, Law, and Social Change (Vancouver: UBC Press, 2007) 31 at 35. Coverage was consistent with the themes Chunn identifies in her analysis of print coverage of feminism and gender equality from 1967 to 2000: a focus on individual cases, a conception of equality as sameness, and an adversarial conception of truth formation.

Hendricks posted particulars of his case, including some of the court documents and legal correspondence, online: Saskatoon Dad <http://www.saskatoondad.com>. News coverage in Saskatchewan also identified ways that people could contribute to a trust fund to finance his litigation costs: see e.g. Darren Bernhardt, "Trust Fund set up for Biological Father” Leader-Post (31 October 2006) A7.

Two of these groups were instrumental in mobilizing a police investigation of allegations of child trafficking, which were ultimately proven to be unfounded: Darren Bernhardt, "Exchange of cash for baby refuted" The Star Phoenix (20 December 2006) A1.

The Turners' lawyer unsuccessfully sought a blanket publication ban: R.F. v. O.B., 2006 SKQB 496, 35 R.F.L. (6th) 163.

Lana Haight "Dad's visit with son cancelled: Appeal prevents city man from seeing infant for first time” The Star Phoenix (28 October 2006) A3.

As an exception, see Susan Brandes, "I am your father” National Post (9 February 2007) A14. Lynn Wells, “Dads depicted as “second-rate”” Leader-Post (9 February 2007) B8. 
between Swan and the Turners, and later, after the trial judgment, as someone who had lost the opportunity to prove himself a responsible parent through no fault of his own. ${ }^{73}$

Notably, newspaper accounts mentioned only once that Dave Turner, who was trained as a heavy equipment operator, was the stay-at-home parent of baby Ian. His actual care of the child over the eight-month period prior to trial, while a profound challenge to dominant constructions of fatherhood, was almost entirely obscured by the focus on "the Saskatoon Dad.” Dave Turner's identity as a social father was also not an interest represented by the fathers' rights groups that supported Hendricks. ${ }^{74}$ This emphasis on genetic rather than social parenthood is consistent with traditional gender-specific roles, which constitute fathers as authority figures rather than caregivers, and may also reflect the stronger resonance genetic parenthood has for men. ${ }^{75}$ According to Barbara Katz Rothman, patriarchal ideology still informs the social meaning attributed to genes, harkening back to notions of children as their father's property or as vessels for the transmission of paternal identity. ${ }^{76}$

In an early interim application, Smith J. noted that biology did not provide a trump card in law. Pursuant to the provincial legislation, the application for custody by Hendricks was governed exclusively by the best interests of the child test rather than a test of parental fitness. ${ }^{77}$ Justice Smith did find that Hendricks and his fiancée, Ruth Taylor, were "adequate" parents, based largely on a parental capacity assessment report that Hendricks had unilaterally tendered in evidence, which relied upon interviews with Hendricks and Taylor and on testimonials from relatives and friends. ${ }^{78}$ Had the test for custody by a biological parent been mere parental fitness, Hendricks would likely have succeeded in his claim.

Following precedent, Smith J. did, however, provide some scope for a biological preference in the application of the best interests test. ${ }^{79}$ In King, McIntyre J. stated that "parental claims ... are entitled to serious consideration” but "must be set aside" where "it is clear that the welfare of the child requires it." ${ }^{80}$ Blood ties must further be considered

See John Gormley, “System Failed Father” The Star Phoenix (2 February 2007) A2; Colby Cosh, “The Saga of Baby Ian” National Post (1 February 2007) A16. See also Collier \& Sheldon, supra note 5 at 183.

$74 \quad$ Both the CCRC and Fathers 4 Justice represented father's rights as primarily flowing from the existence of a biological connection rather than a nurturing, social one. See also the former group's emphasis on "paternity fraud," online: CCRC <http://www.canadiancrc.com/default.aspx>. This emphasis is consistent with a focus on the legal treatment of men upon divorce or separation and the lack of participation by many such groups in the struggles for daycare or childcare, and suggests a greater interest in the reassertion of patriarchal privilege than in a redefinition of fatherhood. Hendricks spoke of his recently deceased father's desire to keep his family members together as motivating his quest for custody: Hendricks, supra note 1 (Evidence, Parental Capacity Assessement Report) at 3-4, 13 [Capacity Assessment].

76 Barbara Katz Rothman, “Daddy Plants a Seed: Personhood Under Patriarchy” (1996) 47 Hastings L.J. 1241. See also R. Alta Charo, "Biological Determinism in Legal Decision Making: The Parent Trap" (1994) 3 Tex. J. Women \& L. 265 at 281.

77 Saskatchewan Act, supra note 11, ss. 8-9. Note that Swan may have purported to act as the legal custodian in transferring guardianship to the Turners, but because the child was transferred from the hospital itself, Hendricks might have argued that she had not resided with the child as per s. 3(2). In $R e$ T.D.E, supra note 56, similar reasoning was relied on but the statutory provisions much more clearly favoured that interpretation.

$78 \quad$ Hendricks, supra note 1 at para. 55.

79 Ibid. at para. 93. Specific factors to be considered under the Saskatchewan Act, supra note 11, s. 8(a), include the quality of the relationship with the child, the material and emotional needs of the child, the capacity of the claimant, the home environment and parenting plans, and wishes of the child. By contrast, the Ontario Act, supra note 11, s. 24(2)(h), specifically includes a relationship by blood or adoption as a factor.

80 King, supra note 8 at para. 27. 
"from the point of view of the significance to the child" ${ }^{81}$ and, according to some authorities, will have a decisive impact only where the claims of custodial and biological parents are otherwise equally balanced. ${ }^{82}$ This test can potentially give biology little weight in determining the outcome since usually some differences can be found between the parties; indeed, de facto care of the child itself can distinguish them. A stronger interpretation of the biological preference, allowing less scope for discretion, emphasizes that the pre-adoptive parent should prevail only where required by the best interests or for grave or weighty reasons. ${ }^{83}$

At the time of trial, baby Ian was eight months old and had been in the care of the Turners since his birth. Justice Smith found that there was no evidence that the child had "so irrevocably attached to the Turners that the cessation of that relationship would, ipso facto, be contrary to the child's best interests." ${ }^{44}$ However, in applying the biological preference to the facts, Smith J. found that the claims of the Turners and Hendricks were not equally balanced. There were too many uncertainties associated with care in the genetic father's home, as elaborated on in Part III.C, below, including the fact that Hendricks' current relationship was "untested by time." 85 Smith J. concluded, “without hesitation,” that baby Ian's interests would be best served in the care of the Turners since this outcome would "best provide for [the child's] health, education, emotional well-being, opportunity for training and economic and intellectual pursuits." ${ }^{\text {"I }}$ In order to provide the custodial parents with "familial calm” ${ }^{87}$ and place them in the "sole parental role," ${ }^{88}$ he suspended access for one year. The suspension of access was subsequently overruled by the Court of Appeal pending hearing of the appeal.

Either a strong or weak variant of the biological preference is facially neutral as between biological mothers and fathers as claimants. The case of Hardcastle ${ }^{89}$ illustrates explicitly, however, how an assumption of sameness between birth parents has the effect of elevating the claims of genetic fathers in third party disputes. In Hardcastle, the Department of Social

Hendricks, supra note 1 at para 93. Studies suggest that knowledge of one's genetic history is important to many adoptees, hence the move towards open adoptions: see Susan M. Wolfgram, "Openness in Adoption: What We Know So Far - A Critical Review of Literature,” online: (2008) 53 Social Work 133 <http://www.scien-socialcareonline.org.uk/>. The Convention on the Rights of the Child, 2 September 1990, 1577 U.N.T.S. 3, art. 8 [U.N. Convention] identifies a child's right "to preserve his or her identity, including nationality, name and family relations as recognized by law without unlawful interference" but what this precisely entails is controversial. Article 9 sets out a right to maintain "personal relations" and "contact" with both parents unless it is "contrary to the child's best interests." See Re British Columbia Birth Registration No. 99-00733, 2000 BCCA 109, 182 D.L.R. (4th) 280, leave to appeal to S.C.C. dismissed without costs or reasons, (2000), 256 N.R. 194 (S.C.C.) [BC Registration (2000)]. In British Columbia Birth Registration Number 030279 (1990), 24 R.F.L. (3d) 437 (B.C.S.C.) [BC Registration (1990)], Prowse J. stated that "[a] perfect balance does not exist simply because both sides are competent to be parents” (at 450).

83 See Hardcastle v. Huculak (1987), 61 Sask. R. 1 (C.A.) [Hardcastle] where the two varied tests appear to merge at a lower threshold, i.e. notwithstanding uncertainties: "the father is not to be deprived of the right to demonstrate his ability to give loving care to his son except where the prospect is so unrealistic as to place an unacceptable risk on the welfare of the child” (at para. 15). For a similar approach to biologically related parties, see Muirhead v. Peters (1995), 14 R.F.L. (4th) 267 (Sask. Q.B.). Some cases also explicitly note that a stricter view of best interests will be applied in adoption cases than in custody cases: see e.g. A.L.J. v. S.J.M. (1994), 98 B.C.L.R. (2d) 237 (S.C.), aff'd (1996), 81 B.C.A.C. 268 [A.L.J.].

Hendricks, supra note 1 at para. 88.

Ibid. at para. 56. See also BC Registration (2000), supra note 82 for similar reasoning.

Hendricks, ibid. at para. 95.

Ibid. at para. 104.

Ibid. at para. 107.

Hardcastle, supra note 83. 
Services admitted that if the birth mother desired custody, the child would have been returned to her. Upon appeal, Wakeling J.A. cited this fact in awarding custody to the genetic father against the birth mother's wishes. ${ }^{90}$ By using the male experience as the unstated norm for comparison and constructing birth mothers and fathers as equal on this basis, the Court in effect strengthens the claims of genetic fatherhood.

\section{B. A COMPARISON OF OUTCOMES BY GENDER}

In a survey of third party cases since 1985, biological mothers advanced custody claims more often than fathers, but fathers succeeded in their claims as often, if not more often, than mothers. Of the 72 cases examined, ${ }^{91}$ fathers and mothers advanced claims jointly in ten cases with three such claims (33 percent) succeeding. Mothers alone advanced claims in 36 of the surveyed cases and fathers in 26. While this marks a dramatic increase in the number of applications by fathers over the pre-1985 survey, it may be argued that fathers should be expected to claim more often than mothers since mothers have generally transferred care of the child to third parties in the first place. The fewer claims by fathers may reflect a lack of knowledge of paternity on their part or a lack of confidence in their eventual success; however, fathers succeeded in six (23 percent), of their claims and mothers in seven (19 percent) of their applications. Moreover, qualitative studies suggest that the decision to relinquish custody on the part of mothers is often subject to pain, ambivalence, and regret. ${ }^{92}$

The absence of a statistical analysis and the interplay of many potential variables make it difficult to determine whether the best interests test is, in fact, being applied differently as between male and female claimants. As an open-ended test, many factors may help to explain judicial outcomes including a concern with biological connection, disruption of bonding processes, the way in which the child came into third party care, and, as discussed below, the relative stability of claimants. In terms of the overall low success rate by mothers, gestation may carry less weight in relation to third parties who have undertaken primary care and are probably able to establish a stronger emotional and psychological bond with the child. Notably, in three of the six cases where the fathers' claims prevailed, the child had been temporarily placed in foster care by the mother rather than in the care of pre-adoptive or custodial parents. ${ }^{93}$ That fathers succeeded in these circumstances suggests that the absence of bonding or class effects may be important, but the outcomes may also reflect other factors that combined to produce stronger claims by the fathers in question as well as more ambivalence on the part of mothers towards paternal care.

Ibid. at 368

As with the pre-1985 cases, the survey was limited to cases assessing the best interests of the child in the context of a claim to custody between a biological parent and an unrelated third party. As such, the survey excludes cases dealing with access, standing to apply for custody, contested adoptions where the issue is simply whether the applicant is a legal parent or whether the consent was validly given, and cases where the applicant is not prepared to assume primary care of the child. Claims arising from apprehensions by state agencies, claims made by step-parents in subsisting relationships with a biological or adoptive parent, and custody claims by birth parents against custodians who are biologically related to either of the parents are also excluded.

92 See Cahn, "Birthing Relationships," supra note 61 at 185-87; Sanger, supra note 61 at 420-22.

$93 \quad$ Hardcastle, supra note 83; T.H. v. C.S. (1991), 110 N.S.R. (2d) 207 (Fam. Ct.) [T.H.]; R.B. v. B.M. (1992), 115 N.S.R. (2d) 104 (Fam. Ct.) [R.B.]. In a fourth case, B.G.S. v. New Brunswick (Minister of Health and Community Services) (1992), 129 N.B.R. (2d) 203 (Q.B.) [B.G.S.], the Minister of Health and Community Services had placed the child for adoption, but no specific evidence was led as to the circumstances of the adoptive parents and the effect of placement on the child. 
The decision of B.C.S. ${ }^{94}$ probably comes closest to replicating the facts in Hendricks, but with a successful female claimant. In this case, the mother temporarily surrendered her oneyear-old child to family friends while she obtained treatment for a severe addiction to crack cocaine. These friends then transferred the child to the birth father who sought custody without disclosing that he had already placed the child with prospective adoptive parents, primarily to end his support payments. ${ }^{95}$ By the time of trial, the child was three years old and had been in the care of the pre-adoptive parents for 20 months. The mother had been clean of substance usage for seven months, had established a new spousal relationship, and was determined to be a fit parent in a unilateral psychological assessment. ${ }^{96}$ In granting custody to the birth mother, Marceau J. found that either home available to the child would provide a safe and nurturing environment, ${ }^{97}$ but that the equally important need of a child to "selfidentify" could only be provided in the home of the biological mother and her family. ${ }^{98}$ In contrast to Hendricks, the past conduct of the mother and the potential instability of her current relationship did not prevent return of her child. The Alberta Court of Appeal affirmed this judgment, holding that the importance given to the biological bond was within the trial judge's discretion and not subject to appellate review. ${ }^{99}$

While fathers' rights groups would claim gender-based discrimination and others may have weighed instability more heavily against the mother's claim, the outcome in B.C.S. can be distinguished from Hendricks on several grounds. Unlike the father in Hendricks, the mother had not only given birth to the child but had maintained a bond with the child over her first year of life that was thereafter sustained through access. The outcome also appeared to be propelled by a strong emphasis on the genetic tie; this emphasis was asserted rather than empirically justified but can work equally to favour genetic fathers. ${ }^{100}$ The finding in B.C.S. was further influenced by the fact that the father's conduct was identified as deliberately deceitful, a finding not made by Smith J. in relation to Swan. The father's conduct was also found to have circumvented the usual child welfare process and thereby put the mother to a higher standard of parenting. ${ }^{101}$

In the next section, I discuss other potential differences, but also significant similarities, in the assessments of the claims of birth mothers and fathers by examining judicial assessments of stability.

B.C.S. v. C.L.J, 2006 ABQB 793, 153 A.C.W.S. (3d) 632, aff'd 2007 ABCA 42, 404 A.R. 19 [B.C.S.]. B.C.S., C.A., ibid. at para. 135.

B.C.S., Q.B., ibid. at para. 103.

B.C.S., Q.B., ibid. at para. 153.

Ibid. at para. 154. It is unclear whether "self-identify" means to know the identity of one's biological parents or to have a primary relationship with them.

Ibid. at para. 20.

100 See e.g. B.G.S., supra note 93 (giving significant weight to blood ties between the father and child in the absence of any evidence regarding bonding of a child in the care of pre-adoptive parents for eight months). For a case involving related parties, see O'Brien v. MacLearn, 2004 NSCA 34, 221 N.S.R. (2d) 297, where the child had been in the care of the maternal grandmother unbeknownst to the father who regularly exercised access. The trial judge found it problematic that the child was getting the message that the "father and his side of the equation are of less importance" (at para. 21). The Nova Scotia Court of Appeal upheld the judgment finding that the trial judge did not err in taking the "father's parental rights into account" and concluding that these rights were not trumped by the status quo, especially given how it was established (at para. 28).

101 In order to be apprehended, a child must generally be found to be in need of protection and at significant risk of injury or neglect. The majority of biological parents whose children are apprehended have had actual care of their children. A comparison of cases such as Hendricks and child protection cases is discussed in another work in progress, but arguably this combination of actual care and biological status justifies a higher threshold in child protection cases generally. 


\section{Assessments OF STABiLity}

Unlike B.C.S., the overriding factor in the determination of the child's best interests in Hendricks was instability. Indeed, in the majority of the post-1985 cases, some dimension of instability (financial, marital, or emotional) has influenced the outcome in favour of the third party caregivers. ${ }^{102}$ Findings of instability work against the claims of both birth mothers and fathers, not only because any change in custody will introduce some measure of uncertainty, but also because third parties are almost always more stable by virtue of their age, financial and marital status, and by the deliberative nature of adoption (generally a result of screening by adoptive parents themselves, state agencies, and birth mothers).

In the following discussion, I look at whether and how various aspects of instability correspond to gendered notions of deserving or good mothers and fathers in the application of the best interests test. According to the dominant white, middle class norms of motherhood, mothers are expected to be primarily responsible for their children. ${ }^{103}$ Fathers, by contrast, have traditionally demonstrated responsibility towards their offspring through the provision of economic support and commitment to a marital relationship with the mother. While mothers/wives were expected to mediate and facilitate paternal attachment to children, a role that is still viewed largely as a maternal responsibility post-divorce, fathers have been expected to provide discipline and guidance, particularly for older children. ${ }^{104}$ Deviation from the traditional ways in which mothers and fathers demonstrated stability does not invariably, but can, hurt both parties in the third party context, albeit in distinctive ways. The impact of gender stereotypes can also be muted or overwhelmed by other variables, some of which may have a more direct connection with child welfare, as appears to have been the case in Hendricks.

\section{PROVISION OF ECONOMIC NEEDS}

The capacity assessment adduced in evidence by Hendricks attested to the existence of a strong work ethic and entrepreneurial spirit, but Hendricks also had a family history of alcoholism, only a grade eight education, a spotty work record, and uncertain economic prospects. He had declared bankruptcy in 2002 and, at the time of trial, was engaged in operating a courier business but could not verify his claimed income of $\$ 35,000$ as he had not paid income tax for three years. ${ }^{105}$ By contrast, the Turners lived on an acreage and enjoyed a substantial income even while the husband undertook primary care of the child. ${ }^{106}$

In his Notice of Appeal, Hendricks claimed discrimination against poor, working class fathers. ${ }^{107}$ In responding to Hendricks' loss, a columnist in the National Post similarly stated, "[i]f the future well-being of a child boils down to the income of its parents, the law might as well let rich families go about kidnapping babies from poor ones in the name of the greater

See e.g. Re T.D.E., supra note 56 at para. 18; BC Registration (2000), supra note 82.

Marlee Kline, "Complicating the Ideology of Motherhood: Child Welfare Law and First Nation Women" (1993) 18 Queen's L.J. 306 [Kline, “Ideology of Motherhood”].

Collier \& Sheldon, supra note 5 at 216.

Capacity Assessment, supra note 75 at 10; Hendricks, supra note 1 at paras. 29-56.

Hendricks, ibid. at para. 60.

See also Twyla Norris, “Adoption ruling appalling” The Star Phoenix (5 February 2007) A8. 
good.”" ${ }^{\text {"108 }}$ Such an account occludes the reality that the Turners, while better off than Hendricks, were not rich and had standing only by virtue of their actual care of the child, obtained with the consent of the birth mother. Indeed, a high threshold standard of de facto care over a substantial time period is generally required to establish standing for third parties. $^{109}$

According to McIntyre J. in King, custody disputes are not to be "determined solely on the basis of the physical comfort and material advantages that may be available in the home of one contender or the other." 110 Judges are nonetheless required to take account of children's economic needs ${ }^{111}$ and, in most cases, they take explicit note of the financial status of the disputants, that is, whether they have steady employment, solid evidence of income, and suitable accommodation for children. While Smith J. identified these facts as relevant, it is unclear how much weight, if any, he gave them.

Poverty may have special significance in claims by fathers given the importance traditionally attached to their role as breadwinners in both popular discourse and law. A "deadbeat dad" is socially defined, first and foremost, as an economically irresponsible father, one who has not paid support. ${ }^{112}$ Lack of support was identified as one reason in Rosta $v$. Thiel ${ }^{113}$ for the father's loss of custody. In J.J.W., ${ }^{114}$ the young father, whose consent to adoption was dispensed with, was working as a dishwasher, had a learning disability, and was living with his mother, whereas the adoptive parents had already established a college fund for the child. While there were legitimate concerns regarding the father's mental health, his current financial status and uncertain prospects clearly weakened his claim. However, in three of the six cases where fathers successfully claimed custody against the wishes of birth mothers, a relative lack of financial resources was irrelevant where the father was otherwise shown to be a "reasonable and responsible young man"115 and where sources of family support were readily available. ${ }^{116}$

An assessment of the case law overall further casts doubt on the proposition that male claimants are being held to a higher standard of economic provision than women. Poor single mothers and fathers are both seen to have unsettled lives arising in large measure from residential insecurity, unemployment, the precariousness of low wage labour, and the

Cosh, supra note 73.

See Letwenuk v. Andrejcin (1995), 138 Sask. R. 295 (Q.B.) [Letwenuk], where the father won interim custody on the basis that care of the child for a four-month period did not give the third parties a "sufficient interest" to ground a claim for custody. See generally G.E.S. v. D.L.C., 2006 SKCA 79, 270 D.L.R. (4th) 597.

King, supra note 8 at para. 27 [emphasis added].

Saskatchewan Act, supra note 11, s. 8(a).

Deena Mandell, 'Deadbeat Dads': Subjectivity and Social Construction (Toronto: University of Toronto Press, 2002) at 56.

(1986), 72 N.S.R (2d) 33 (S.C. (T.D.)).

J.J.W. v. R.C.C.B., 2006 SKQB 24, 146 A.C.W.S. (3d) 676 [J.J.W.].

Hardcastle, supra note 83 at para. 10.

T.H., supra note 93; Miller v. Wood (1989), 63 D.L.R. (4th) 216 (B.C.C.A.) [Miller]. In two of the remaining cases, the fathers were found financially able to provide for the child: C.K. v. K.E. (1985), 2 C.N.L.R. 38 (N.W.T.S.C.) [C.K.]; B.G.S., supra note 93, and in a third, economic status was not discussed: R.B., supra note 93. 
difficulties of reconciling paid work and child care. Women lost where they had inadequate housing and financial support; ${ }^{117}$ men lost for much the same reasons. ${ }^{118}$

Moreover, biological mothers are more likely to be poor than fathers and, in this sense, economic instability likely affects more mothers than fathers. ${ }^{119}$ Economic and social marginalization often accounts for why mothers transfer custody to third parties in the first place, particularly since the decline in domestic adoptions in the 1970s and 1980s. Not surprisingly, a disproportionate number (34 percent) of the female claimants in the surveyed cases since 1985 have involved Aboriginal ${ }^{120}$ and racialized birth mothers, ${ }^{121}$ although a relatively high number ( 25 percent) of the male claimants have also been identified as Aboriginal and racialized fathers. ${ }^{122}$ Mothers succeeded in 25 percent of the cases in which they claimed custody either alone or jointly with the father; fathers succeeded in 22 percent of such cases.

A best interests test that defines stability exclusively in terms of economic or residential security will reinforce the subordination of poor, often racialized, biological parents. To minimize these effects so far as possible, judges must identify whether basic needs can be met, must define responsible care in light of existing systemic constraints and cultural norms, and ascertain whether there are strengths having a more direct and substantial connection with the child's emotional and psychological needs. A biological preference may also help to screen out the effects of class or race bias, but is itself discretionary. Dorothy Roberts has argued that how we view biology and the significance we attribute to it is also a product of historically and culturally specific perceptions and social mores that are influenced by white and class privilege. ${ }^{123}$ The import of biology may thus also be subtly discounted for children of racialized and poor parents.

See e.g. BC Registration (1990), supra note 82; S.J.D.v. J.S., 2000 SKQB 523, 101 A.C.W.S. (3d) 939; K.M.H. v. N.E.R., [1995] B.C.W.L. 1640 (S.C.) [K.M.H.]; D.W. v. G.C. (1996), 174 N.B.R. (2d) 173 (Q.B.) [D.W.]; Wilson v. Lockrey, [1994] O.J. No. 3209 (Ct. J. (Prov. Div.)) (QL).

See J.F.M., supra note 56; J.N.Z. v. J.D., [1994] B.C.J. No. 969 (S.C.) (QL) [J.N.Z.]; N.P. v. LDS Adoption Services, 2006 ABQB 78, 392 A.R. 282. More generally, see D.H.v. H.M., [1999] 1 S.C.R. 761, aff'g [1997] B.C.J. No. 2144 (S.C.) (QL) [D.H.], where the Supreme Court of Canada affirmed a trial judgment awarding custody to affluent, white adoptive grandparents over an Aboriginal grandfather who cared for the child for one and a half years but was unemployed and in the midst of moving back to his reserve.

In 2003, 31 percent of unattached women had incomes below the after tax low-income cut off compared to 28 percent of male counterparts; 38 percent of single mothers had low incomes compared to 13 percent of single fathers: Colin Lindsay \& Marcia Almey, "Income and Earnings" in Women in Canada: A Gender-based Statistical Report, 5th ed. (Ottawa: Ministry of Industry, 2006) 133 at 143-44.

See N. (M.L.) v. British Columbia (Superintendant of Family and Child Services), [1990] B.C.J. No. 1652 (S.C.) (QL) [N. (M.L.)]; J.F.T.v. C.A.S. (1993), [1994] 1 W.W.R. 419 (B.C.C.A.) [J.F.T.]; A.P.G. v. K.H.A. (1994), 164 A.R. 47 (Q.B.) [A.P.G.]; Googoo v. Campbell, [1994] N.S.J. No. 648 (Fam. Ct.) (QL) [Googoo]; Fleury v. Littlecrow, [1987] W.D.F.L. 217 (Sask. Fam. Ct.); J.R. v. D.W., [1992] B.C.J. No. 1610 (S.C.) (QL); L.A.P. v. R.P., [1996] B.C.J. No. 2353 (S.C.) (QL); Sam v. August, [1998] B.C.J. No. 2879 (S.C.) (QL); and see the prominent pre-1985 case of Racine v. Woods, [1983] 2 S.C.R. 173 [Racine]. Kline has argued that Aboriginal mothers are prejudiced because of their social location and its linkages to racial oppression and colonialism: Kline, "Ideology of Motherhood," supra note 103 at 312-13. Four of the male claimants in the post-1985 survey were Aboriginal and a further four involved other racialized fathers. 


\section{COMMITMENT AND RESPONSIBILITY}

The search for a stable parental figure suggests a need for proof that the parent will or is likely to provide continuity of care and sustain a commitment to the welfare of the child over the long-term. The commitment of mothers is put at issue where they have consented to the surrender of primary care and then attempted to regain custody of the child. In case reports, birth mothers have often experienced extreme financial stress, little if any social support, depression, shame or anxiety, substantial pressure from family members and social workers, or fear of disclosure to their parents. More often than not, however, mothers who have consented to adoption after birth but then seek to revoke their consent are found to have consented freely and voluntarily. ${ }^{124}$

Commendably, judges do not always find that a mother's consent to adoption, even if deemed voluntary, amounts to abandonment of a parental role. Rather than being construed as a relinquishment of parental duties, the mother's choices may be seen as evidence of a responsible effort to ensure the child's well-being. ${ }^{125}$ While such assessments appropriately place the mother's conduct in its context, they also frequently reinforce the adoptive parents' claim. Since King, the chance of finding that a return to the mother is in the child's best interests has been substantially prejudiced by the transfer of primary care.

As for fathers, until the late 1980s, a genetic connection alone was widely assumed to be insufficient to sustain paternal attachment over time. ${ }^{126}$ Even where unmarried, noncohabiting fathers applied for custody and hence demonstrated interest, they were apt to be stereotyped as irresponsible because responsible fatherhood was exercised and facilitated primarily through marriage. In 1992, in Re D.T., Chipman J.A. of the Nova Scotia Court of Appeal indicated that the "only credential" the applicant father had in his claim to custody was his biological fatherhood. ${ }^{127}$ At best, this was taken to be a "neutral fact," which presumably carried no weight at all. ${ }^{128}$ Ultimately, there was too little evidence to show that the father "is fit to maintain a meaningful relationship with the child." 129

The U.S. Supreme Court has given responsible conduct significant weight in dealing with the constitutional status of unwed fathers, but has yet to decide a case involving newborns, where there typically has been little or no opportunity to demonstrate responsibility or commitment in relation to the specific child. Other American courts are divided on whether a biological father must be provided with this opportunity, but in a few notorious cases where fathers were found to have standing and to have met the test of fitness, they won custody of

See e.g. S.F. v. C.C.S., 2004 SKQB 396, 134 A.C.W.S. (3d) 643.

See e.g. Re Mugford (1969), [1970] 1 O.R. 601 (C.A), aff'd (1969), [1970] S.C.R. 261; C.D. v. P.B., 2006 BCSC 1515, 152 A.C.W.S. (3d) 1076; S.J.D. v. J.S., 2000 SKQB 523, 101 A.C.W.S. (3d) 939 [S.J.D.]; D.A.G. v. T.L. (1990), 96 N.S.R. (2d) 250 (Co. Ct.). Bartlett argues that parenthood should not be viewed as a matter of contractual exchange and parental consent should hence not conclusively preclude revocation, supra note 9 at 205. See also Robert Leckey, Contextual Subjects: Family, State, and Relational Theory (Toronto: University of Toronto Press, 2008), noting the need for rules to account for the relative weight of biological ties, the impact of bonding, and the reliance interests of pre-adoptive parents (at 56-60).

C.E.S., supra note 43.

Re D.T., supra note 43 at para. 46.

Ibid.

Ibid. at para. 40. 
children who had spent years in the care of pre-adoptive parents. ${ }^{130}$ In response to such cases, some states provided fathers with a statutory opportunity to assert an interest (through, for example, a putative father registry) but within a very limited time frame. ${ }^{131}$ In some cases, judges have also examined whether the father acted promptly in seeking custody or whether he supported the mother during pregnancy as relevant to commitment and his standing to advance a claim. A Florida court, for example, rejected a father's claim where he was physically and emotionally abusive to the mother who was also malnourished during her pregnancy. ${ }^{132}$

Hendricks did act promptly in initiating proceedings to identify his paternity and assume full custody after gaining knowledge of the child's birth. Indeed, by stepping up to the plate, Hendricks appeared to distinguish himself as a father who was prepared to undertake responsibility for the consequences of his sexual conduct. However, it is unclear what weight, if any, Hendricks' past conduct towards the birth mother was or should have been given in relation to the child's best interests. Swan testified that Hendricks was emotionally insecure and controlling and that he had stalked her through constant phone calls and the physical monitoring of her residence. Their relationship ended after what Smith J. described as an "alcohol-fuelled violent incident" ${ }^{\text {133 }}$ and what Swan described as a physical roughing up when she told him she wanted to end their romantic relationship. ${ }^{134}$

While conduct must be relevant to a present ability to parent, ${ }^{135}$ it is now widely accepted that spousal violence can adversely affect children. ${ }^{136}$ In Re T.D.E., Kent J. asserted that an abusive father having limited sexual contact with the mother should not be on an equal footing with her in terms of guardianship. ${ }^{137}$ Given outstanding allegations of violence committed by the father against the birth mother, Kent J. also found that the birth father lacked the necessary stability to be a parent to the child. ${ }^{138}$ It is unclear whether or to what extent Hendricks would have put the child at risk in light of evidence that his was an isolated incident of physical violence. Hendricks' counsel also suggested that his client's physical surveillance of Swan was an attempt to monitor her health and disrupt her drug habit. ${ }^{139}$

In Re Clausen, 502 N.W.2d 649 (Mich. Sup. Ct. 1993), application for stay denied; DeBoer ex rel. Darrow v. DeBoer, 509 U.S. 938 (1993); In re Kirchner, 649 N.E. 2d 324 (Ill. Sup. Ct. 1995), application for stay denied; O'Connell v. Kirchner, 513 U.S. 1138 (1995). Laura Oren notes that 30 days after birth is the typical time frame: "Thwarted Fathers or Pop-Up Pops?: How to Determine When Putative Fathers Can Block the Adoption of Their Newborn Children" (2006) 40 Fam. L.Q. 153 at 171, 180-82. Only fathers who comply with the statutory requirements win custody over pre-adoptive parents, assuming they are fit parents. In re Adoption of Baby E.A.W., 658 So.2d 963 (Fla. Sup. Ct. 1995). See June Carbone, "The Missing Piece of the Custody Puzzle: Creating a New Model of Parental Partnership” (1999) 39 Santa Clara L. Rev. 1091 at 1134. Hendricks, supra note 1 at para. 15.

134 Lana Haight, "P.A. couple can give child best home, birth mom tells court" The Star Phoenix (22 December 2006) A7.

135 See e.g. Saskatchewan Act, supra note 11, s. 8(c).

See Nicholas Bala, Peter G. Jaffe \& Claire V. Crooks, "Spousal Violence and Child-Related Cases: Challenging Cases Requiring Differentiated Responses” (2007) 27 Can. Fam. L.Q. 1; Children’s Law Reform Act, supra note 11, s. 24(4), which makes relevant violence or abuse against a parent of the child committed at any time.

137 Re T.D.E., supra note 56 at para. 15.

138 See also J.N.Z., supra note 118, where the mother falsely said the father was unknown because of his past abuse.

Counsel further pointed out that Swan had suffered no injuries, had continued to work for him, and was not afraid of him: Trial Transcript, supra note 62 at 579-83. Hendricks testified that he himself was a victim of physical violence in his relationship with his wife, from whom he was separated but not yet divorced. There was also independent evidence that Hendricks had not been violent in his current relationship or in the relationship with K.Z. 
Disturbingly consistent with the typical profile of an abusive personality, however, was his refusal to take responsibility for the violence against Swan. He initially denied the incident by affidavit, and at trial, admitted hitting Swan but blamed it on his susceptibility to alcohol consumption following an industrial accident and his "problematic relationship with Rose."140

Of greatest apparent concern to Smith J. was the potential instability of Hendricks' eightmonth relationship with his fianceé since they had planned to jointly parent baby Ian and both had been involved in many short-term and, in Taylor's case, several violent relationships. ${ }^{141}$ Conjugal or familial stability is not directly relevant to the ability to care for a child but it can be relevant to the continuity of the child's primary relationships and his or her emotional security. Despite relatively high divorce rates, marriage has traditionally been viewed as the pre-eminent signal of stability. In contrast, judges have often identified single parenthood as an inherently unstable family form even though a single parent may be more likely to develop a primary bond with a child that can be sustained through a successive conjugal relationship. ${ }^{142}$ Hendricks was able to conform to the dominant heterosexual familial model by virtue of his impending marriage but the short-term nature of his current and past relationships raised concerns regarding the stability of the child's primary relationships. While Hendricks' sexual history ${ }^{143}$ contributed to a perception of instability, nothing suggests that it was otherwise interpreted as deviant or immoral conduct. In post-1985 cases, the sexual conduct of mothers has likewise been identified as evidence of instability ${ }^{144}$ but also as promiscuous, ${ }^{145}$ implicitly immoral, ${ }^{146}$ or more recently, explicitly irrelevant. ${ }^{147}$

Finally, there was troubling evidence led at trial suggesting that Hendricks had not been significantly involved in the lives of two daughters, both of whom had been adopted. Hendricks acknowledged his paternity in the case of the eldest 14-year-old daughter who had re-established contact with him but, as Smith J. noted, Hendricks could not recall her birth date under cross-examination. ${ }^{148}$ The second alleged daughter was born in 2003 and her

Hendricks, supra note 1 at para. 16.

Ibid. at paras. $37,49$.

See e.g. BC Registration (1990), supra note 82. In J.W.S. v. N.C.M. (1993), 10 Alta. L.R. (3d) 395 (Q.B.) [J.W.S.], the birth father was living with his family but the judge was concerned that he would relocate with the child if he married. The eventual introduction of a new mate may or may not be more likely than the separation or divorce of the adoptive parents, but it would not likely have represented a significant loss of relational stability for the child given the likelihood of continuing contact with both her father and biological relatives. Compare T.H., supra note 93 where the judge was not troubled by this having found that the father had the desire and ability to become an active "psychological parent" to the child (at para. 19). For the positive impact of an intact heterosexual relationship, see also D.M. $v$. Saskatchewan (Minister of Social Services) (1979), 5 Sask. R. 1(Q.B.); J.F.M. v. V.P., 2003 ABQB 834, 127 A.C.W.S. (3d) 854; L.L.R. v. R.M.C., [1996] S.J. No. 819 (Q.B.) (QL), where the court expressed surprise that the adoptive parents had separated in light of a home study report identifying them as stable. The claims of birth mothers, where successful, were also substantially aided by the eventual return of the birth father in Nguyen v. McGinn (1989), 97 A.R. 38 (Q.B) and by the formation of a new common-law relationship in B.C.S., supra note 94. Justice Smith described this history as "serial monogamy": Hendricks, supra note 1 at para. 37, but Hendricks also testified to overlap between his sexual relationships, i.e. he was dating another woman before his relationship with Swan ended: Trial Transcript, supra note 62 at 385.

See K.K.W. v. E.J.R. (1989), 102 A.R. 106 (Q.B.) where the mother alleged sexual abuse as a teenager and O.R. v. G.L. (1994), 146 N.B.R. (2d) 1 (Q.B.) where the mother's inability to identify the father was considered evidence of instability (at para. 33). F. (G.E.) v. M. (T.L.) (1988), 88 A.R. 259 (C.A.)

Re S.L.J. (1989), 102 A.R 118 (Q.B.), referring to bonding, group sex, etc.

Khan v. Kong (2007), 164 A.C.W.S. (3d) 296 (Ont. Sup. Ct. J.).

Hendricks, supra note 1 at para. 34. 
mother (K.Z.) testified that Hendricks was the only possible father but that he had abruptly ended their relationship after being notified of her pregnancy. ${ }^{149}$ Unfortunately, Smith J. did not assess this evidence in light of Hendricks' flat denial, but it may well have intensified doubts regarding Hendricks' stability. ${ }^{150}$ Judges have awarded custody where a parent has acknowledged problematic behavior and demonstrated the strength or ability to overcome past patterns of conduct. ${ }^{151}$ Justice Smith was apparently not convinced of the potential for such a long-lasting change.

\section{CARE AND NURTURANCE}

Judges appear to look more closely for evidence of bonding between mothers and children than is the case with fathers. ${ }^{152}$ While this tendency is consistent with traditional stereotypes of motherhood, mothers are also more likely than fathers to have actually cared for their children. The claims of mothers appear to be particularly at risk if they have not sought and exercised access. ${ }^{153}$

Unlike fathers, mothers' choices are also more likely to be constructed in terms of selflessness or selfishness. This dichotomous construction may reflect the real effects of bonding through gestation and childbirth but may also be influenced by traditional gender stereotypes. Women who separate from their children may be viewed as selfish to the extent that motherhood is identified with care and self-sacrifice. ${ }^{154}$ However, the decision to separate may also be viewed as an act of selflessness and reflect a need to "retain motherhood as a state of continuous giving." 155 Justice Wilson, in Racine, for example, constructed the birth mother as selfish in seeking the return of her child by stating: "It takes a very high degree of selflessness and maturity, for most of us probably an unattainable degree, for a parent to acknowledge that it might be better for his or her child to be brought up by someone else.”" ${ }^{\not 156}$ In a number of other cases, judges have described the transfers of children by birth mothers as acts of unselfishness; ${ }^{157}$ the motives of male claimants for relinquishing custodial or parental status are rarely framed in these terms.

Nurturing has not been seen as a role that comes naturally to fathers. Although there are increasingly optimistic assessments of "converging gender roles" ${ }^{\text {"158 }}$ and nurturant fatherhood

Trial Transcript, supra note 62 at 628-31.

There was yet another allegation during trial of a child fathered by Hendricks in 2005 but a DNA test did exclude this possibility.

See e.g. K.E.J.v.D.L.J., 2002 ABQB 188, [2002] 6 W.W.R. 124; B.G.S., supra note 93. See also A.L.J., supra note 83.

See e.g. BC Registration (1990), supra note 82; B.C.S., supra note 94.

See e.g. Googoo, supra note 120; BC Registration (1990), ibid.; A.P.G., supra note 120; and explicit mention of minimal access in W.R.L. v. C.D.G. (1994), 46 A.C.W.S. (3d) 883 (Man. Q.B.); Fluter v. Tawiyaka (1998), 80 A.C.W.S. (3d) 587 (Man. Q.B.).

See Sanger, supra note 61.

Katherine O’Donovan, “'Real’ Mothers for Abandoned Children” in Susan B. Boyd \& Helen Rhoades, eds., Law and Families (Aldershot: Ashgate, 2006) 201 at 222.

Racine, supra note 120 at para. 23.

BC Registration (1990), supra note 82; T.H., supra note 93 at para. 15; Re Mugford, supra note 125, (Shroeder J.A.); M. (C.G.) v. M. (M.D.) (1989), 68 Alta. L.R. (2d) 136 at para. 14 (Q.B.).

Time spent on childcare by fathers with children under 19 at home has increased on average since 1986 but it has increased more for mothers (from 1.4 to 2 hours per day) than fathers (from 0.6 to 1 hour per day) in 2005: Katherine Marshall, “Converging gender roles” (2006) 7:7 Perspectives on Labour and Income 5 at 11 . 
is a newly idealized role for men, ${ }^{159}$ women continue to be disproportionately responsible for caring for or organizing the care of children during the course of subsisting relationships and in facilitating contact and a relationship with fathers at the point of divorce or separation. ${ }^{160}$ A number of factors may constrain the extent to which men in fact nurture, among them: dominant conceptions of masculinity; male violence; homophobia; ${ }^{161}$ the demands of paid employment and gender-based economic inequalities; mothers' anxieties and resistance; and, not least, men's material interest in the status quo. ${ }^{162}$

Drawing on the work of Carol Tronto, Carol Smart distinguishes between the work of "caring for" children and "caring about" children. ${ }^{163}$ Although Hendricks had not cared for baby Ian, he was portrayed in media reports as a parent who deeply cared about his child. He was frequently described as weeping, tearful, fighting back tears, choked up, and fumbling for words. ${ }^{164}$ The sheer intensity of the emotional connection Hendricks communicated, while potentially perceived as grandstanding, was useful in representing his claim as part of the "new fatherhood" 165 and in simultaneously distancing his claims from those of a sperm donor or a “deadbeat dad.” Unlike a sperm donor, Hendricks had not contracted to produce a child nor relinquished any claim and his emotional response suggested that he was not disconnected from his offspring. By contrast, the Turners were portrayed as more detached, acquisitive, and manipulative of the process through what appeared to be deliberate delay, unreasonable conditions on access, and efforts to avoid media attention. ${ }^{166}$

Hendricks' emotional appeals may, however, have underlined concerns about his emotional stability, particularly since affective expressiveness is not a characteristic typically associated with dominant masculinity. Findings of emotional or psychological instability represent significant barriers to custody for both men and women. ${ }^{167}$ Hendricks had been hospitalized for depression in 2000 and the testimony of both the birth mother and a former girlfriend suggested that he was easily frustrated and often emotionally distraught. ${ }^{168}$ Even though Smith J. acknowledged that Hendricks showed "grit and determination in his pursuit for custody," he was also described as "emotionally fragile”169 and as having, along with his fianceé, "significant psychological wounds."

Mandell, supra note 112 at 32.

Boyd, supra note 31.

Nancy E. Dowd, “Rethinking Fatherhood” (1996) 48 Fla. L. Rev. 523 at 527, 533.

Richard Collier, "A Hard Time to Be a Father?: Reassessing the Relationship Between Law, Policy, and Family (Practices)” (2001) 28 J.L. \& Soc’y 520 at 539.

Carol Smart, “The Legal and Moral Ordering of Child Custody” (1991) 18 J.L. \& Soc’y 485 at 488.

See e.g. Darren Bernhardt, "Biological father has emotional first visit with infant son” Leader-Post (3 November 2006) F5.

See Collier's discussion of this in the U.K., supra note 162 at 526-34.

“Custody case requires quick action by court," Editorial, The Star Phoenix (1 November 2006) A10. See also Haight, supra note 70.

See e.g. J.J.W., supra note 114 where the birth father had unresolved emotional issues and suicidal thoughts (at para. 26); S.J.D., supra note 125; K.A.E. v. D.R. (2000), 94 A.C.W.S. (3d) 929 (Ont. Sup. Ct. J.); J.F.M., supra note 56. For women, see Re R.H.J. (1998), 231 A.R. 56 at para. 4 (Q.B.), where the mother was also described as "emotionally fragile" and as having intellectual challenges; D.W., supra note 117; Family Youth and Child Services of Muskoka v. L.R. (1998), 80 A.C.W.S. (3d) 341 (Ont. Ct. J. (Gen. Div.)).

Trial Transcript, supra note 62 at 559, 617-18.

Hendricks, supra note 1 at para. 46.

Ibid. at para. 56. 
There was little independent evidence and no explicit reference in the judgment to Hendricks' individual capacity to nurture or “care for” baby Ian. In third party custody disputes, adoptive parents typically have the advantage of having proven their ability to care for the specific child in addition to the positive effects of bonding. Lack of experience with child care has been found not to prejudice a birth father's claim where the support of family members is available, provided the evidence suggests that the father is prepared to assume personal responsibility for the child's care. ${ }^{171}$ Actual care should favour a claim but judges should also not simply assume that single fathers are incompetent to nurture, particularly where lack of experience arises from lack of opportunity.

\section{AUTHORITY AND CONFLICT}

Related to the concern with familial stability and commitment is the concern with the exercise of authority over children and the potential for conflict among multiple caregivers. In B.C. Registration (1990), the British Columbia Court of Appeal found that return of an eleven-month-old child to the genetic father, who was supported by the birth mother and his own mother, carried an increased risk of insensitive or inconsistent caregiving through uncertainties associated with multiple caregiving. ${ }^{172}$ In J.W.S., the intense feud between the birth parents and their families was the decisive factor favouring the pre-adoptive parents. ${ }^{173}$

Parents obviously need the authority to act in a child's best interests and conflict among parents has been empirically identified as a significant risk to child welfare. ${ }^{174}$ However, judicial skepticism towards multiple and single parent situations may falsely assume that the nuclear family form minimizes the potential for conflict. This preference for a socially conservative family form is also linked to the patriarchal common law discourse of fatherhood, in which the core meaning of parenthood resides in the exercise of authority over children. $^{175}$

In Hendricks, Smith J. held that Hendricks could obtain access but could not occupy a parental role in his relationship with baby Ian. Over the next one-year period, moreover,

See e.g. R.B., supra note 93 at para. 8 (the father provided “excellent” care during access); T.H., supra note 93 (the father was receiving counselling in parenting skills). See also J.J.W., supra note 114 at para. 21, where Rothery J. indicated that the case was "not about the paternal grandmother's ability to help the birth father"; J.F.M., supra note 56 (the birth father had little experience in caring for children and no family support); J.N.Z., supra note 118 (the father planned that his fianceé, a woman still in Egypt, would take care of the child, leaving her own infant child behind); Wright v. Clarke, [1988] B.C.J. No. 1347 (C.C.W.) (QL) (if custody went to the father, the child would probably be raised by his aunt); A.B. v. Newfoundland and Labrador, 2004 NLSCUFC 8, [2004] N.J. No. 89 (QL); and T.I. v. A.K., [1985] O.J. No. 764 (Prov. Ct. (Fam. Div.)) (QL) (the father's parents were to raise the children, would care for the child while he was going to school and working); A.L.J., supra note 83 at para. 57 (the father's mother was to care for the child although the father planned to do the "disciplining and the teaching"). Mothers may be more readily assumed to undertake personal care of children even if they need or receive family support. This assumption reflects prevalent gendered parenting patterns but may be wrong in individual cases.

Supra note 82. Justice Prowse noted that a child removed from its custodians could suffer distress if the new caregiver was insensitive, inconsistent, or lacking in resiliency. Uncertainties of concern included the potential for conflict between birth mother and paternal grandmother, and the fact that the partners of both birth parents were either ambivalent about or antagonistic towards custody. J.W.S., supra note 142. See also J.N.Z., supra note 118 (the conflict between the religious and cultural views of the birth mother and father favoured the third party custodians).

174 See Martha Shaffer, "Joint Custody, Parental Conflict and Children’s Adjustment to Divorce: What the Social Science Literature Does and Does Not Tell Us” (2007) 26 Can. Fam. L.Q. 285 at 289, 305-309.

175 Lessard, supra note 51 at 194 . Some cases also speak of the need for a male role model: K.M.H., supra note $117 ; D . W$., supra note 117. 
Smith J. denied access in order to foster the final stages of attachment of the child to the Turners and avoid any difficulties the child might experience in "reconciling all the complicated adult relationships in his life." ${ }^{176}$ While an access order of any kind would have reduced the likelihood of a future adoption order in favour of the Turners in Saskatchewan, ${ }^{177}$ Smith J. appeared otherwise anxious to shore up their parental authority and identity.

It is interesting that concerns were not raised in relation to access by the birth mother. Of course, Hendricks may have been seen as more of a threat to the Turner's parental authority, not because fathers have traditionally been cast as authority figures in the family, but because of a concern that Hendricks personally would deliberately or unconsciously undermine the Turners' parental role. ${ }^{178}$ However, access had been established by the time of trial, was proceeding without evidence of any harmful effects, and could have been made subject to counselling ${ }^{179}$ or altered in the event of conflict. The reality of adoption is that the child in fact has multiple parents and the positive benefits for the child of knowing this reality from an early age is increasingly recognized in the shift towards more open adoptions. ${ }^{180}$

\section{SUMMARY}

The above review of case law raises some evidence of the effect of gender stereotypes in the treatment of claims by birth parents that can disadvantage both mothers and fathers in distinctive ways, but particularly poor, single, often racialized claimants. While differences can be identified, many of them tightly bound up with traditional familial ideology and the effects of class and race-based disadvantage, there is little evidence that mothers are favoured relative to fathers in the judicial assessment of third party custodial claims. There is, moreover, little evidence that Hendricks' specific claim to custody was substantially prejudiced by gendered norms in light of concerns regarding his emotional well-being and relational stability. In the next section, I examine the position of non-claimant parents, emphasizing the erasure of the birth mother as a further limitation of a formal equality approach.

Pursuant to The Adoption Act, 1998, supra note 12, an adoption order operates to terminate existing rights to access and disallow future applications on the part of birth parents (except for step-parent adoptions).

See e.g. see A.L.J., supra note 83, where the trial judge suspended access until the child was at least six years old because the birth father lacked maturity and sensitivity and third parties associated with the father's First Nation could undermine the adoptive parent's status given the "highly politicized" nature of their claim (at para. 115).

179 See e.g. L.A.P.v. R.P., [1996] B.C.J. No. 2353 (S.C.) (QL), where the trial judge did not want to sever the child's relationship with her birth parents through adoption and also believed that joint custody was inappropriate given the lack of a history of co-operation. Access outside the home of the custodial parents was ordered to occur only after the child and birth parents received counselling and only after a clinical psychologist and family mediator (agreed upon by the parties) identified the child as psychologically ready.

Wolfgram, supra note 81, suggests that in a healthy adoption, the birth family should be recognized but also notes a lack of research on when contact is beneficial and when it is likely to cause problems. 


\section{The Disappearing Biological Parent/Mother}

\section{A. INVISIBILITY}

Swan wanted an open adoption, was represented by counsel, and had testified at trial. Despite all this, important dimensions of her experience were not visible in most media accounts and the legal judgment. Her Aboriginal heritage was mentioned rarely, and primarily only because Swan's mother, with whom she had a troubled relationship, belatedly asserted an interest in custody as a way of maintaining that heritage for baby Ian. ${ }^{181}$ Invisible as well were the many reasons why Aboriginal women are disproportionately unable to rear their children, reasons that are rooted in the impact of the colonial regime imposed on First Nations, poverty, racism, and the destructive effects of residential schools. ${ }^{182}$ Rather, Smith J. attributed the situation before him to "the often complex circumstances that flow from the unfolding lives of real people with human frailties." "183 In suggesting that Swan opted for adoption because she was "self-aware of her own failings," 184 he presented the obstacles to her care as entirely of her own making.

Swan testified that she chose the Turners as the custodians of her child because they could give the child "stability, family, a good home," ${ }^{185}$ could not otherwise have children, ${ }^{186}$ and were agreeable to a customary adoption with the possibility of access on her part. ${ }^{187}$ Swan's difficult relationship with her own mother also precluded reliance on extended family care. In the absence of these and the above facts, however, Swan appeared in media reports to have simply chosen to drop out of her child's life and to have no ongoing interest in his future well-being.

In a number of cases, Aboriginal culture and heritage have been found insufficient to warrant a return of custody to birth parents. ${ }^{188}$ Justice Wilson's statement in Racine that the importance of Aboriginal identity abates with time ${ }^{189}$ has been highly disputed, in part because Aboriginal identity may become even more important to children in their

Interestingly, Smith J. implicitly questioned the grandmother's claim in noting that "she, herself, is not biologically First Nations, but rather married into that status": Hendricks, supra note 1 at para. 25. This suggests that culture is not a lived experience but rather a biological attribute.

See Kline, "Ideology of Motherhood," supra note 103; Vera J. Roy, "The Erasure of Ms. G.: The Cultural Specificity of Substance Abuse and Adjudication without Imagination” (2005) 20 C.J.L.S. 107. Hendricks, supra note 1 at para. 109.

Ibid. at para. 18.

Trial Transcript, supra note 62 at 559.

Ibid. at 596.

Ibid. The agreement provided that Rose could exercise access "provided that the timing and terms of such access are agreeable to the Guardians." The parties also promised to jointly consult regarding exposure of the child to his heritage and provided for the possibility of access by Rose's family members subject to their joint approval: Hendricks, supra note 1 at para. 18.

Racine, supra note 120; J.F.T., supra note 120; D.H., supra note 118; Alberta (Director of Child Welfare) v. G.N., 2002 ABQB 1108, 332 A.R. 41; Algonquins of Pikwakanagan First Nation v. Children's Aid Society of Toronto (2004), 238 D.L.R. (4th) 745 (Ont. Sup. Ct. J.); Kenora Patricia Child and Family Services v. D.O., [2001] 4 C.N.L.R. 103 (Ont. Ct. J.); A.P.G., supra note 120. See also Catholic Children's Aid Society v. A.V.W. (2002), 113 A.C.W.S. (3d) 273 (Ont. C.A.) (denying access to the child's birth mother even for four hours annually); Van de Perre v. Edwards, 2001 SCC 60, [2001] 2 S.C.R. 1014

Racine, ibid. at para. 28. 
adolescence. ${ }^{190}$ Other than noting that the child should be registered with a First Nation if possible, ${ }^{191}$ the racial and cultural heritage of baby Ian was not considered relevant to the disposition in Hendricks. In most other surveyed cases, race and ethnicity are acknowledged as having some importance, although less so it seems in the case of Aboriginal mothers who tend to lose their custody claims. ${ }^{192}$

In Hendricks, the erasure of the birth mother (as a non-claimant) arguably made it easier to overlook the relevance of the child's Aboriginal heritage to his future well-being. All of the contending parties, except for Swan, were non-Aboriginal, but only the Turners had ongoing contact with First Nation communities and a positive relationship with Swan. ${ }^{193}$ Custody with the Turners thus had the potential to sustain more of the relationships, both social and biological in origin, that would have a bearing on baby Ian's identity as he matured. Justice Smith never addressed the question of whether Swan, in light of the conflict between her and Hendricks, could have maintained a relationship with the child had he been the primary custodian. ${ }^{194}$ This kind of balancing exercise can only be addressed under a standard that is more broadly based than parental fitness.

\section{B. The Birth Parent's Wishes AND Plans}

Another issue submerged in the judgment was the significance of the birth mother's wishes. In newspaper accounts, the right of the biological father to veto third party care over the objections and wishes of the mother was never questioned. It was simply assumed that Swan had no further role after having transferred custody of the child to the Turners. By contrast, Smith J. at least acknowledged that Swan had placed the child with a "loving," “educated, mature and well-grounded” couple ${ }^{195}$ and noted her belief that Hendricks was not emotionally healthy enough to raise the child. ${ }^{196}$

In the survey of post-1985 cases, non-claimant birth parents took disparate positions on the custody claim of the other parent but more birth mothers opposed the father's claim than vice versa. In almost half of the surveyed decisions, the non-claimant parent was either unknown, uninvolved, or proceeding jointly with the other birth parent. Of the remaining cases, the father supported the mother's claim in seven and opposed her in six, ${ }^{197}$ whereas the mother supported the father's claim in one case and opposed it in 21 cases. Where mothers were strongly opposed, their views were often extensively discussed and in one case,

See Kenn Richard, “A Commentary Against Aboriginal to non-Aboriginal Adoption” (2004) 1 First Peoples Child \& Family Review 101; Patricia A. Monture, "A Vicious Circle: Child Welfare and the First Nations” (1989) 3 C.J.W.L. 1 at 13; Anne McGillivray, "Therapies of Freedom: The Colonization of Aboriginal Childhood” in Anne McGillivray, ed., Governing Childhood (Aldershot: Dartmouth, 1997) 135 at $170-74$.

Hendricks, supra note 1 at para. 26.

192 See e.g. N. (M.L.), supra note 120; A.P.G., supra note 120; Googoo, supra note 120; J.F.T., supra note 120.

193 Hendricks, supra note 1 at paras. 58, 63. Swan's mother had initially supported Hendricks in his claim and he suggested that she could have acted as a conduit to the child's Aboriginal heritage. However, at trial, she herself unexpectedly claimed custody over both Hendricks and the Turners, and alleged in testimony that the adoptive mother was a "witch": Trial Transcript, supra note 62 at 54. Compare J.N.Z., supra note 118, where the conflict between the religious and cultural views of the birth mother and father aided the pre-adoptive parents in their claim.

Hendricks, supra note 1 at paras. 18, 65.

Ibid. at para 17.

Downs v. Ross, [1991] S.J. No. 389 (Q.B.) (QL); B.C.S., supra note 94 (an effort to reduce support). 
given explicit weight. ${ }^{198}$ In six cases, custody was nonetheless awarded to the fathers. ${ }^{199}$ In two of these, it is unknown whether the birth mothers might have opted for an abortion or decided to retain custody themselves had they known the fathers would be granted custody. ${ }^{200}$

Neither the birth mother's or father's position should constitute a veto on the other's claim but, given her intimate and extensive involvement up to that stage, the mother's opposition should, at a minimum, signal a need for careful scrutiny of the father's claim and counter any strong presumption in favour of a biological parent. Having regard to the birth mother's wishes would offer her some assurance that her plans will be respected, encourage her to make responsible plans for the child, and thereby promote the best interests of children. ${ }^{201}$ Failure to provide this kind of assurance to birth mothers exacerbates the stress, uncertainty, and adverse psychological and emotional effects of pregnancy and childbirth for both mothers and their fetuses. ${ }^{202}$ This assurance could be particularly important for women who cannot easily access abortion or for whom abortion is emotionally and psychologically costly.

Those mothers who arrange for primary care and proceed with their pregnancy in reliance on those plans should be assured that their arrangements will be given at least serious consideration. This would be analogous to the "serious consideration" that the Supreme Court of Canada in Gordon v. Goertz directed be given to custodial parents in relocation cases. $^{203}$ Such a position acknowledges the critical role of the gestational mother, assumes that she has a continuing interest in her child's well-being (even absent primary care), and treats her as more than just a vehicle for the production of the child.

As indicated earlier, acknowledging the process of gestation in this way may be criticized as promoting a form of biological essentialism, an assumption that biological mothers invariably know best where their child's best interest lies. However, as demonstrated in the press coverage of the Saskatoon Dad case, ignoring the gestational role of the mother can foster a form of genetic essentialism. Moreover, concerns with biological essentialism are arguably not very significant in this context since the involvement of other primary caregivers itself disrupts or undermines any conflation of birth with conventional

N.N. v. S.C.H. (1993), [1994] B.C.W.L.D. 100 (Sup. Ct.).

Hardcastle, supra note 83; Miller, supra note 116; T.H., supra note 93; R.B., supra note 93; B.G.S., supra note 93; C.K., supra note 116.

Miller, ibid.; Hardcastle, ibid. In T.H., ibid., the mother indicated that if the father was successful she did not want access or to pay support. In Letwenuk, supra note 109, after the birth father won interim custody because the third parties were found not to have an interest sufficient to claim custody, the birth mother advanced, but ultimately lost, custody and in Brass v. Taypotat, [1999] S.J. No. 422 (Q.B.) (QL), the birth mother revoked her consent to a voluntary committal (the child was in foster care awaiting adoption) in favour of an ultimately unsuccessful claim by her own mother against the birth father. Nancy S. Erickson, “The Feminist Dilemma Over Unwed Parents' Custody Rights: The Mother's Rights Must Take Priority" (1984) 2 Law \& Inequality 447 at 458, argues that giving birth fathers rights increases the pressure on women to abort or care for children themselves even when they would prefer third party care: see BC Registration (2000), supra note 82, where the birth mother changed her position after the birth father commenced his action, but in LaCarte, supra note 27, the birth mother was prevented by the Ontario statute from revoking her consent and seeking custody so long as the child remained in the care of the pre-adoptive parents.

Bartlett, supra note 9 at 312.

See e.g. Anja C. Huizink et al., "Stress during pregnancy is associated with developmental outcome in infancy” (2003) 44 Journal of Child Psychology \& Psychiatry \& Allied Disciplines 810.

[1996] 2 S.C.R. 27 at para. 48. 
motherhood. Biology is obviously not destiny where the birth mother does not undertake the primary care role, which was instead assumed, as in Hendricks, by the social father.

Since the child is not a possession the mother can "give away," her wishes also cannot be treated as conclusive. The mother is not always in the best position to know the child's interests and, in some instances, her wishes may in fact simply replicate the idealized conventional family form. For example, in Hardcastle, ${ }^{204}$ the birth mother apparently believed that the child's interests would be better served through adoption by a financially stable couple. The Court found, however, that the birth father was a "reasonable and responsible" young man who should be given custody. ${ }^{205}$

There is also the countervailing risk, identified earlier, that the mother's gestational care or reasons for the surrender of care will be more closely scrutinized and her position discounted or assessed accordingly. This risk can only be offset or countered by a sensitive, contextualized assessment of the mother's situation. In Hendricks, for example, Swan admitted that she had problems with substance abuse and felt unable to provide the kind of care her son required. Substance abuse is a complex problem occurring in almost all societies and ethnic groups. To the extent that drug usage is disproportionately a problem in Aboriginal communities, however, it should be understood not wholly as an individual problem or responsibility but also as "part of a profound pattern of poverty, disempowerment and cultural dislocation" imposed on Aboriginal peoples. ${ }^{206}$ While unable to undertake primary care, mothers like Swan should also not be assumed to lack the capacity to know their child's best interests. Susan C. Boyd's study of mothers addicted to illicit drugs suggests that the mothering role is often central to them and addicted mothers are often falsely assumed to be incapable of nurturing and socializing children and making responsible choices. $^{207}$

Last, fathers may complain that giving weight in this way to the mother's position constitutes unfair treatment in light of the fact that they have little say in whether the mother proceeds with the pregnancy and may be obligated to pay child support if she chooses to parent herself (against their wishes) or if the third party seeks child support. Genetic fathers are unable to force women not to have an abortion. ${ }^{208}$ If, however, the mother proceeds with the pregnancy, they may be liable for support even where they have been actively deceived as to the use of birth control and have themselves favoured abortion or adoption as alternatives to childbirth. ${ }^{209}$

Supra note 83.

Ibid. See also T.H., supra note 93 at para. 15. The desire for a "two parent" family appears in a number of cases.

Roy, supra note 182 at 113.

Susan C. Boyd, Mothers and Illicit Drugs: Transcending the Myths (Toronto: University of Toronto Press, 1999) at 35. Boyd also contests the assumed causal connection between illicit drug usage (as opposed to alcoholism) and fetal harm. 
An assessment of what has been labelled "coerced fatherhood" and the controversial effects of privatized support are beyond the scope of this article. ${ }^{210}$ Interestingly, the physical involvement of mothers in gestation and birth is now being cast predominantly as a source of power for mothers, having the potential for misattribution or concealment. ${ }^{211}$ Historically, however, unmarried mothers experienced this “power” more as a source of social stigma or as an onerous or unfortunate responsibility forced upon them by biology. Fathers, by contrast, have not borne the brunt of stigma nor are they now forced to undergo intrusive and potentially painful procedures or arrange for the primary care of the child, although they can "step up" if they so choose. ${ }^{212}$

Fathers may complain of a lack of correspondence between responsibilities and rights but genetic fatherhood does generally confer the right to apply for custody or access and an opportunity to establish a relationship with the child. Moreover, as neither mothers nor fathers were ordered to pay support in any surveyed case in which unrelated third parties obtained custody, the support obligation appears more of a theoretical than a real possibility. ${ }^{213}$ In any case, the mere existence of a potential support obligation cannot be considered conclusive of a right to custody, as readily acknowledged in the post-marital context. Collapsing the distinction between child support and custody would reduce the child-parent relationship to a matter of financial exchange, and treat the child as an appendage or as property of the payor parent.

\section{THE “BAD” MOTHER}

In some of the media representations and fathers' rights activism surrounding the Hendricks case, there are traces of a more direct reassertion of patriarchal authority, a blaming of the birth mother as immoral and irresponsible, and an unexamined privileging of fathers' interests at the expense of mothers' interests.

On the few occasions Swan was mentioned in newspaper reports, she was not portrayed as a person deserving of sympathy or as a mother who was trying to secure the best interests of her child. Swan was most commonly identified as a drug abuser, but also as sexually

See Jessica L. Roberts, "Conclusions from the Body: Coerced Fatherhood and Caregiving as Child Support” (2005) 17 Yale L.J. 500; Sally Sheldon, "Unwilling Fathers and Abortion: Terminating Men's Child Support Obligations?” (2003) 66 Mod. L. Rev. 175.

Mary Burbach \& Mary Ann Lamanna, "The Moral Mother: Motherhood Discourse in Biological Father and Third Party Cases” (2000) 2 J.L. \& Fam. Stud. 153 at 189.

See Karen Czapanskiy, "Volunteers and Draftees: The Struggle for Parental Equality” (1991) 38 UCLA L. Rev. 1415.

213 Biological parents nonetheless have primary responsibility under the Child Support Guidelines: see Wright v. Zaver (2002), 59 O.R. (3d) 26 (C.A.). Interestingly, the Turners initially claimed child support but dropped the claim at trial. From a tactical perspective, they may have wanted to scare Hendricks off but the support claim probably damaged their public profile as they appeared to be even more acquisitive in their quest for not only the child but monetary support as well. Provincial jurisdictions have assumed disparate positions on the financial liability of persons standing in the place of parents: for example, statutory provisions are broad enough to include unrelated third parties who have demonstrated a settled intention to treat a child as a child of their own family in Saskatchewan (The Family Maintenance Act, 1997, S.S. 1997, c. F-6.2, s. 2) and Ontario (Family Law Act, R.S.O. 1990, c. F.3, s. 1(1)), but in Quebec, persons in loco parentis are not liable for support at all and in Alberta, the category is restricted to those in spousal or interpersonal relationships (Alberta Act, supra note 11, s. 48(1)(a)). Note also that unmarried, non-cohabiting parents with custody (who are disproportionately women) have no rights to compensatory spousal support, even though they may suffer many of the same opportunity costs arising from child care as married or cohabiting spouses. 
promiscuous (since “any number of men might have been the father”) ${ }^{214}$ and as a "proficient liar." ${ }^{215}$ All such characterizations are markedly consistent with traditional moralistic notions of unwed mothers as both dishonest and promiscuous. ${ }^{216}$

A dominant strategy of Hendricks' counsel throughout the trial was to try to establish that Swan had acted dishonestly by deliberately concealing the identity of Hendricks as the birth father. However, the trial judge found that Swan in fact believed Hendricks was not the father because Hendricks had advised her that he was sterile as a result of his industrial accident. ${ }^{217}$ Newspaper accounts did not report this testimony nor ever suggest that a misrepresentation on Hendricks' part contributed to the dilemma that ensued.

Deliberate concealment of her pregnancy was potentially a problem because Swan was assumed to have at least a moral duty to consult with the father and provide him with an opportunity to establish paternity. Even where a father may contest adoption proceedings through birth registries and statutes requiring actual notice, lack of timely disclosure of paternity may prevent him from applying for custody before an adoption or reduce the strength of his claim if bonding becomes an issue. ${ }^{218}$ Framed in terms of the child's interests, the concern is that the child will be denied the opportunity to know his or her genetic origins and develop an ongoing relationship with his or her genetic father. ${ }^{219}$

What both fairness between parents and a child's best interests require, however, depends on a prior assessment of the significance of a genetic tie to both parent and child, an interest one judge described as "intangible, and not readily put into words," circumstances surrounding the individual claim. Fathers' rights groups have been accused of greatly exaggerating the frequency of misattributed paternity and little is known regarding the incidence of or reasons for deliberate concealment. ${ }^{221}$ In only two of the 26 post-1985 cases (apart from Hendricks) in which fathers applied for custody did the mother fail to tell the father of her pregnancy. ${ }^{22}$ In both cases, the fathers had the opportunity to notice that the mothers were visibly pregnant but did not make inquiries. In Re D.T., the mother mistakenly believed that the father knew but was disinterested and the Nova Scotia Court of Appeal held

214 Cosh, supra note 73.

215 Gormley, supra note 73. Swan admitted that she had misled her mother into believing that Hendricks was the birth father because she did not want her mother to know that she had had sexual relations with more than one man: Lana Haight, “Mom tried to keep dad’s identity a secret” Leader-Post (22 December 2006) B3.

216 In her study of unwed mothers up to the 1960s, Chambers documents how both judges and social workers constructed non-cohabiting unwed mothers precisely in these ways as the "loc[i] of sin," Chambers, supra note 17 at 30, 31, 39, 50-56.

217 Hendricks, supra note 1 at para. 1. A former girlfriend (K.Z.) testified that Hendricks had conveyed the same story to her before she became pregnant with his child in 2003: Trial Transcript, supra note 62 at 628.

218 The birth father registry established in B.C. provides a registrant with the right to receive notice of a proposed adoption if the claim is registered before or after the child's birth or no later than 150 days after placement of the child. Fathers who have had sexual relations but have lost contact with the mother can register to ensure that they receive notice of any proposed adoption. For birth mothers, this process is likely preferable to mandating disclosure by birth mothers in adoption proceedings as it minimizes privacy concerns and delays. However, a registry would not necessarily prevent transfers of guardianship or custody.

219 See U.N. Convention, supra at note 81.

$220 \quad$ BC Registration (1990), supra note 82 at 456.

221 Lyn Turney, “Paternity Secrets: Why Women Don’t Tell” (2005) 11 Journal of Family Studies 227 at 228.

222 Re D.T., supra note 43; A.L.J., supra note 83. In Foley v. Kurulak (1996), [1997] 1 W.W.R. 558 (B.C.S.C.), the mother was not herself aware of her pregnancy until childbirth. 
that in any case, she was under no legal duty to inform the father of his paternity. ${ }^{223}$ Qualitative research in Australia suggests that mothers do not tell or reveal the identity of fathers for complex reasons including uncertainty about the identity or whereabouts of the father, fear arising from violent or emotionally abusive relationships, or the risk of public shaming of the women and their children. ${ }^{224}$ In coverage of the Saskatoon Dad case, Swan was assumed to have a moral duty to disclose paternity to the genetic father even though she experienced her relationship with Hendricks as invasive, controlling, and in the end, physically violent. The possibility of an angry or spurned mother acting out of sheer spite in not disclosing paternity cannot be denied, but there is far more empirical evidence validating the existence of concerns arising from violence and abuse that may warrant non-disclosure.

In the present context, there is also an issue as to whether the way in which a child came into the care of the custodians is relevant to an assessment of the best interests of the child. In B.C.S., ${ }^{225}$ the father had been actively deceitful in placing the child with the pre-adoptive parents without the birth mother's knowledge, but the judge did not explain how this factor was relevant in assessing the claims of the birth mother and the innocent pre-adoptive parents in relation to the child's best interests. In three other cases, the mothers misled or failed to inform the adoption agencies of the father's identity. ${ }^{226}$ In J.N.Z., the mother left her home province alleging physical, verbal, and emotional abuse by the father before and during her pregnancy. ${ }^{227}$ In J.W.S., the mother secretly left her home state, bore the child in Georgia, and travelled to California where her child was placed for adoption with Canadian parents. ${ }^{228}$ In all these cases, the mother's conduct was not taken to be relevant to an assessment of the best interests of the child and custody remained with the pre-adoptive parents. ${ }^{229}$

There are circumstances, such as kidnapping, where the best interests principle would clearly be pre-empted by the importance of the integrity and proper administration of the criminal justice or judicial system. ${ }^{230}$ Unlike kidnapping, it is not a criminal offence to fail to advise a father of a pregnancy and, as indicated, even the moral basis for disclosure of

Re D.T., ibid.

Turney, supra note 221 at 234-43.

Supra note 94.

See e.g. BC Registration, (2000), supra note 82; J.N.Z., supra note 118; J.W.S., supra note 142. In two cases falling outside the criteria of our case survey, mothers lied to fathers about the birth of the children they placed for adoption. In L.L. v. Saskatchewan, 2003 SKQB 8, 229 Sask. R. 49, the mother falsely said she had miscarried and the father was subsequently unsuccessful in obtaining disclosure of the adopted child's identity, and in a recent Ontario case, where custody has yet to be decided on its merits, the birth mother falsely advised the father that the child was stillborn: LaCarte, supra note 27.

J.N.Z., ibid.

J.W.S., supra note 142. Note that the father and his family sued the mother and her family for intentional infliction of emotional distress. See Smith v. Malouf, 722 So.2d 490 (Miss. Sup. Ct. 1998). For similar facts see Kessel v. Leavitt, 511 S.E.2d 720 (W.Va. 1998), certiorari refused, 625 U.S. 1142 (1999), where damages in the millions were awarded based on findings of fraud and tortious interference with a father's parental rights as against the mother's parents, brother, and lawyer. For cases of misattributed paternity or 'paternity fraud' in Canada, see Cornelio v. Cornelio (2008), 94 O.R. (3d) 213 (Sup. Ct. J.) where K.M. van Rensburg J. found no duty to disclose an extramarital affair, and refused to order repayment of child support already paid by the husband. For the relationship between tort and family law, see Frame v. Smith, [1987] 2 S.C.R. 99. A discussion of the tortious implications of concealment or misrepresentation is beyond the scope of this article.

The removal of the children for the purposes of placement in another province could, however, constitute an offence in some jurisdictions, see e.g. in Ontario, Child and Family Services Act, supra note 12, ss. 176(1), 141(1)-(4).

Christine Davies, “Racial and Cultural Issues in Custody Matters” (1993-94) 10 Can. Fam. L.Q. 1 at 13. British Columbia expressly allows adoption orders to be set aside in the event of fraud, but only if such an outcome is in the best interests of the child: Adoption Act, supra note 12, s. 40(b), and in Alberta, see Child, Youth and Family Enhancement Act, supra note 12, s. 73.1(1). 
paternity depends greatly on the specific surrounding circumstances. That such a general duty is being discussed ${ }^{231}$ is further evidence of the dramatic shift in weight accorded to claims of fathers and the increasing pressures on mothers to mediate and facilitate relationships between fathers and children, even outside the context of marriage or cohabiting relationships.

\section{CONCLUSION}

Many possible reforms might minimize the trauma associated with cases like Hendricks and warrant further research and debate. Least controversial are those measures that would expedite the hearing of fathers' claims, particularly determinations of paternity, ensure interim access, and, as importantly, facilitate access to legal assistance for both biological parents. More controversially, three commentators in the Saskatoon Dad case suggested that the provincial social service agency should have used due diligence and taken Hendricks' attempts to identify his child more seriously. ${ }^{232}$ As Smith J. noted, Hendricks was treated simply as a male voice asserting paternity when he attempted to locate his son. ${ }^{233}$ What "due diligence" would have required of state officials, however, is unclear. Is the suggestion that the child should have been transferred to Hendricks against the birth mother's wishes based simply on his assertion of paternity? Or is it that the child should have been taken into foster care even though the child was not at risk since the birth mother had made responsible plans for his care?

Some provinces have gone further than others to regulate adoption processes through constraints on private or direct placements or on custody claims where a child has been placed for adoption, ${ }^{234}$ but no legislature appears to have gone so far as to prohibit outright voluntary transfers of custody to third parties without court approval. Voluntary care arrangements by parents are relatively common, although most are made on a temporary basis and between family members. While court orders may often be required for health, educational, or other administrative purposes, ${ }^{235}$ requiring court approval of all transfers of custody or guardianship would seem to constitute a significant intrusion on private

See e.g. the critical response to Re BC Birth Registration Number 06-014023, 2007 BCSC 1441, 285 D.L.R. (4th) 716, where Smith J. held that a genetic father who was not acknowledged by the birth mother and had failed to register under the birth father's registry was not entitled by statute to notice of the child's proposed adoption. According to the article "Adoption law needs overhauling to give children knowledge about their birth dads” The Vancouver Sun (3 October 2007) A16: “obviously, this is not in the best interests of the children" because it fails to ensure that many children have an opportunity to know their birth fathers.

Cosh, supra note 73; Gormley, supra note 73; Brandes, supra note 71.

$233 \quad$ Hendricks, supra note 1 at para. 7.

Ontario makes it an offence for a person other than a society or license to "place a child for adoption" (excepting family adoptions) and prohibits custody claims after expiration of the time period for revocation of consent for so long as the child remains in the pre-adoptive parents' care: Child \& Family Services Act, supra note 12, ss. 139(2), 141(1)-(4), 176(1). By contrast, a birth parent in Saskatchewan can place a child up for adoption directly, without the intervention of an agency, or transfer guardianship to an agency for that purpose: The Adoption Act, 1998, supra note 12, s. 13(1); in Alberta, see Child, Youth and Family Enhancement Act, supra note 12, s. 63(3).

In the tragic case of six-year-old Katelynn Samson, an application by Donna Irving was precipitated by a need for a custody order before the child could access school counselling services. The Court hearing the application did ask about the biological father but his whereabouts were unknown and the birth mother did not want to release any details. In the wake of Samson's murder by Irving and her partner, the Ontario legislature recently passed Bill 133, Family Statute Law Amendment Act, 1st Sess., 39th Leg., Ontario, 2009, cls. 6-9 (assented to 14 May 2009), requiring that non-parents submit a recent police record check and a report from children's aid societies in custody applications. 
agreements. The U.K. requires that "private fostering” arrangements (that is, arrangements involving neither parents or close relatives and intended to exceed 28 days) be reported to local child welfare authorities. ${ }^{236}$ The implementation of such a reform requires more debate, but it would, in any case, not obviate the need on the part of the putative father to establish paternity before advancing a claim to custody.

In practical terms, fathers' rights activism in relation to the Saskatoon Dad case probably did more than legal reform could to strengthen the role and voice of biological fathers in these disputes. Despite the fact that Hendricks lost his custody claim at trial, most adoptive parents would regard the Turners' situation as a nightmare to be avoided at all costs. The massive, intrusive publicity that accompanied the case $\mathrm{e}^{237}$ (complete with an RCMP investigation into allegations of baby trafficking), the escalating legal costs, the prospect of long-standing appeals (had Hendricks not died), and the potential obstacle to a future adoption order serve as a lesson to all prospective adoptive parents that they run a tremendous risk of disruption if the birth father has not consented from the outset.

These same events, however, may only have exacerbated the dilemmas facing birth mothers, particularly those involved in violent relationships. A birth father's registry could assist in knowing whether fathers intend to advance a claim but only if such registries could be accessed by birth mothers or prospective adoptive parents and if notice or the lack of it was timely and irrevocable. Taking due account of the birth mother's wishes and acknowledging her interest in the future welfare of the child in custody disputes might also help. Most importantly, providing adequate and culturally appropriate supports for mothers to raise their children as single parents, or alternatively, facilitating access to abortion and other forms of contraception, could substantially minimize the number of women who confront such dilemmas. fostering.org.uk.>.

237 See Bernhardt, supra note 67. When Hendricks initially contacted the media, before he initiated a court application, he did not use pseudonyms and the parties' true identities were widely published. This case, among others, raises questions as to whether lack of anonymity in media coverage is prejudicial to children's best interests and if so, how this might be addressed. 